\title{
Direct Radiative Effect by Multicomponent Aerosol over China*
}

\author{
Xin Huang, ${ }^{+}$Yu Song, ${ }^{\#}$ Chun ZhaO, ${ }^{@}$ Xuhui CaI, ${ }^{\#}$ Hongsheng Zhang, ${ }^{\circledR}$ And Tong Zhu \\ + State Key Joint Laboratory of Environmental Simulation and Pollution Control, Department of Environmental Science, \\ Peking University, Beijing, and Institute for Climate and Global Change Research, and School of Atmospheric Sciences, \\ Nanjing University, and Jiangsu Collaborative Innovation Center for Climate Change, Nanjing, China \\ " State Key Joint Laboratory of Environmental Simulation and Pollution Control, Department of Environmental Science, \\ Peking University, Beijing, China \\ ${ }^{\circledR}$ Atmospheric Science and Global Change Division, Pacific Northwest National Laboratory, Richland, Washington \\ \& School of Physics, Peking University, Beijing, China
}

(Manuscript received 22 May 2014, in final form 23 December 2014)

\begin{abstract}
The direct radiative effect (DRE) of multiple aerosol species [sulfate, nitrate, ammonium, black carbon (BC), organic carbon (OC), and mineral aerosol] and their spatiotemporal variations over China were investigated using a fully coupled meteorology-chemistry model [Weather Research and Forecasting (WRF) Model coupled with Chemistry (WRF-Chem)] for the entire year of 2006. This study made modifications to improve the model performance, including updating land surface parameters, improving the calculation of transition-metal-catalyzed oxidation of $\mathrm{SO}_{2}$, and adding heterogeneous reactions between mineral dust aerosol and acid gases. The modified model generally reproduced the magnitude, seasonal pattern, and spatial distribution of the measured meteorological conditions, concentrations of $\mathrm{PM}_{10}$ and its components, and aerosol optical depth (AOD), although some low biases existed in modeled aerosol concentrations. A diagnostic iteration method was used to estimate the overall DRE of aerosols and contributions from different components. At the land surface, the incident net radiation flux was reduced by $10.2 \mathrm{~W} \mathrm{~m}^{-2}$ over China. Aerosols significantly warmed the atmosphere with the national mean DRE of $+10.8 \mathrm{~W} \mathrm{~m}^{-2}$. BC was the leading radiative heating component $\left(+8.7 \mathrm{~W} \mathrm{~m}^{-2}\right)$, followed by mineral aerosol $\left(+1.1 \mathrm{~W} \mathrm{~m}^{-2}\right)$. At the top of the atmosphere (TOA), BC introduced the largest radiative perturbation $\left(+4.5 \mathrm{~W} \mathrm{~m}^{-2}\right)$, followed by sulfate $\left(-1.4 \mathrm{~W} \mathrm{~m}^{-2}\right)$. The overall perturbation of aerosols on radiation transfer is quite small over China, demonstrating the counterbalancing effect between scattering and adsorbing aerosols. Aerosol DRE at the TOA had distinct seasonality, generally with a summer maximum and winter minimum, mainly determined by mass loadings, hygroscopic growth, and incident radiation flux.
\end{abstract}

\section{Introduction}

Atmospheric aerosol, mainly comprising sulfate, nitrate, ammonium, black carbon $(\mathrm{BC})$, organic carbon (OC), dust, and sea salt, is generated from primary anthropogenic and natural emissions as well as by secondary transformation. Aerosol has impacts on radiative transfer directly through scattering and absorbing solar

\footnotetext{
* Supplemental information related to this paper is available at the Journals Online website: http://dx.doi.org/10.1175/JCLI-D-1400365.s1.

Corresponding author address: Yu Song, Room 211, Lao Di Xue Building, Peking University, No. 5 Yiheyuan Road, Haidian District, Beijing, China.

E-mail: songyu@pku.edu.cn; tzhu@pku.edu.cn
}

radiation and indirectly by modifying microphysical properties of clouds, thereby exerting a cooling or heating effect on the planet (Rosenfeld et al. 2008; Myhre et al. 2013). For instance, BC leads to a global warming effect because of its absorption of solar radiation (Ramanathan and Carmichael 2008; Bond et al. 2013). In the meantime, sulfate is capable of cooling the climate system by reflecting sunlight and serving as cloud condensation nuclei (Kiehl and Briegleb 1993). Unlike greenhouse gases, aerosol is not that well mixed and is substantially influenced by meteorological conditions (e.g., vertical turbulence and precipitation), chemical transformation (photochemical, aqueous, and heterogeneous reactions), aerosol microphysics (nucleation, coagulation, and condensation), and removal processes (wet scavenging and dry deposition). Consequently, the size distribution, mass concentration, chemical composition, and mixing state of 
aerosols are extremely variable in space and time, leading to great heterogeneity in their optical properties and subsequent radiative effect.

China has recently been experiencing an economic boom featuring fast urbanization, growing industrial production, tremendous energy consumption, and an increasing number of vehicles. Major pollutants, such as sulfur dioxide $\left(\mathrm{SO}_{2}\right)$, oxides of nitrogen $\left(\mathrm{NO}_{\mathrm{x}}\right), \mathrm{BC}$, and $\mathrm{OC}$, are intensively emitted because of the rapid economic growth, deteriorating China's air quality. As a traditionally agricultural country, China has a dense rural population associated with agricultural production, biofuel combustion, and field burning of crop residues (a widespread practice in China's rural areas), all of which are also important sources of atmospheric trace gases and particulate matter, especially ammonia $\left(\mathrm{NH}_{3}\right), \mathrm{BC}$, and OC (Huang et al. 2012b,a). In 2012, China consumed around 3.6 billion tons of coal-equivalent energy, $70 \%$ of which was contributed by coal combustion (National Bureau of Statistics of China 2013), causing a total of approximately $30 \mathrm{Tg}$ of $\mathrm{SO}_{2}$ emitted into the atmosphere annually (Lu et al. 2011; Q. Zhang et al. 2012). China also features high BC concentrations, which are mainly caused by residential combustion. It is estimated that about $1.8 \mathrm{Tg}$ BC was emitted annually in China in the late 2000s (Q. Zhang et al. 2009; Lu et al. 2011), accounting for approximately one-fourth of global emissions. Besides anthropogenic emissions, northern China is one of the world's largest dust source regions, with an annual mineral dust emission of 42.6 Tg (Xuan et al. 2000). The coexistence of many primary and secondary pollutants makes the atmospheric oxidation capacity, aerosol chemical compositions, and optical properties unique in China. In recent decades, a heavy burden of $\mathrm{PM}_{10}$ (particles of 10 microns or less in aerodynamic diameter in the ambient air) with mass concentrations exceeding $100 \mu \mathrm{g} \mathrm{m}^{-3}$ has been frequently and extensively observed across China (X. Zhang et al. 2012). Such high concentration aerosols could result in complex and significant effects on China's climate change.

Since the first estimates of sulfate aerosol direct radiative effect (DRE) in 1991, the DRE of multiaerosol components has been studied during the last two decades with a global aerosol model (Charlson et al. 1991; Schulz et al. 2006; Myhre et al. 2013; Su et al. 2013). On the one hand, coarse spatial resolution and handling of complexities in the cloud and aerosol schemes in the global models may introduce great uncertainties in the prediction of aerosol DRE. On the other hand, aerosol DRE varies significantly in space. China is a major source region of trace gases and aerosols, especially in terms of BC, as mentioned previously. The BC DRE is several times higher over China than over other regions around the world (Bond et al. 2013) and could play an important role in the regional climate system. Consequently, it is imperative to evaluate aerosol DRE over China on a regional scale. The DRE of aerosol over China has been studied since the 1990s (Wang et al. 2003; Xu et al. 2003; Li et al. 2009; Wang et al. 2010; H. Zhang et al. 2009, 2012). However, previous studies have several inadequacies. First, ammonium and nitrate in East Asia were usually overpredicted by models, and one possible reason is overestimation of $\mathrm{NH}_{3}$ emissions (Kim et al. 2006). A newly available bottom-up ammonia emission inventory and inversion of ammonium wet deposition data also suggest that China's ammonia emission was overestimated in previous studies (Huang et al. 2012a; Paulot et al. 2014). Simultaneously, as an important source of atmospheric trace gases and particulate matter, BC and particularly biomass-burning emissions were usually omitted in the model (Zhuang et al. 2011; Park et al. 2014). Second, most chemical transport models do not well represent the transitionmetal-catalyzed oxidation of $\mathrm{SO}_{2}$ and heterogeneous reactions, which are of critical importance in secondary aerosol formation, particularly for sulfate (Usher et al. 2003; Harris et al. 2013). Third, most existing studies that focused on aerosol DRE over China applied offline modeling, in which the chemical model is run after the meteorological simulation is completed ( $\mathrm{Li}$ et al. 2009; H. Zhang et al. 2012). The interpolation in space and time and inconsistency in physical parameterizations can induce significant bias in aerosol modeling. Meanwhile, offline models cannot provide further insight to aerosol-radiation-climate interactions, but such feedback is crucial for understanding climate change (Zhang 2008). To get a better idea of aerosol DRE over China, numerical studies were conducted for the entire year of 2006. Here, we applied updated emission inventories, refined land surface parameters, and improved the chemistry module of sulfate production to better characterize the overall DRE due to aerosol and contributions from individual components.

\section{Model and data description}

\section{a. Model configurations}

The Weather Research and Forecasting (WRF) Model coupled with Chemistry (WRF-Chem) version 3.4.1, a fully coupled, online meteorology-chemistry model (Grell et al. 2005), was used to investigate the DRE of aerosol over China. The Carbon Bond mechanism, version Z (CBMZ), gas-phase chemistry mechanism and the Model for Simulating Aerosol Interactions and Chemistry (MOSAIC) scheme for aerosol simulation were selected (Fast et al. 2006). All major aerosol components were simulated simultaneously. Aerosols were assumed 
to be spherical particles. The size distribution was divided into four discrete size bins defined by their lower and upper dry particle diameters (0.039-0.156, 0.156-0.625, $0.625-2.5$, and $2.5-10.0 \mu \mathrm{m})$. Geometric mean diameters were used when simulating various chemical and microphysical processes of aerosols. Aerosols in each bin were assumed internally mixed. The extinction, single-scattering albedo (SSA), and asymmetry factor of aerosols were computed as a function of wavelength and threedimensional positions. Specifically, each chemical constituent of the aerosol was associated with complex indices of refraction. For each size bin, the refractive indices of the aerosols was derived by volume averaging, and the Mie theory was used to find the extinction efficiency, the scattering efficiency, and the intermediate asymmetry factor. Optical properties were then determined by summation over all size bins (Fast et al. 2006).

Since our simulation treat aerosols as internal mixed, in order to diagnose the DRE of individual aerosol components, calculations of aerosol optical properties and radiative transfer were performed multiple times at each time step: with and without one aerosol component and its associated water, following $\mathrm{C}$. Zhao et al. (2013b). Specifically, an iterative diagnostic procedure was embedded in the module that was used to calculate aerosol optical properties. The module averaged the refractive indices for each size bin based on the volumeaveraging mixing rule and then performed Mie computations at each time step. The refractive indices of various components were listed in Barnard et al. (2010). The diagnostic method developed subtracts one aerosol component and also its associated water while averaging the refractive indices. In addition, the reduced total aerosol masses, but the same aerosol number, shift the aerosol size distribution toward smaller particles for calculating aerosol optical properties. For one specific component, its AOD was equal to the AOD difference between two computations: the standard computation with all aerosol components included and the diagnostic computation with its mass and associated water removed during refractive indices calculation and following Mie routine. Aerosol radiative feedback was coupled with the radiative transfer model (RRTMG) for both shortwave and longwave radiation. Likewise, the DRE of one specific aerosol component was derived from the difference between the aforementioned two parallel runs. This method is superior compared to a traditional method of running the model several times with the emission of a specific aerosol component turned off because it saves computing time and also strictly estimates only the direct radiative effect of aerosols. The so-called direct aerosol radiative effect estimated from the traditional method has been defined as a radiative flux perturbation (RFP)

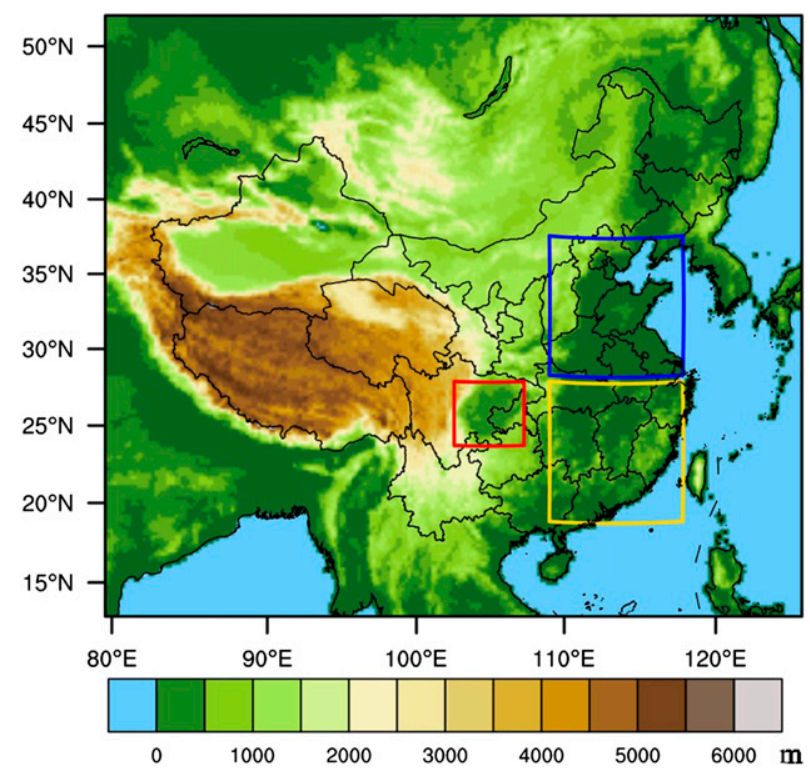

FIG. 1. Model domain and topographic field (m); small islands in the South China Sea are not included. The rectangles represent north China (blue rectangle), the Sichuan basin (red rectangle), and south China (yellow rectangle).

that includes the change of radiative fluxes from aerosolcloud interaction (Haywood et al. 2009; Lohmann et al. 2010). Details on the diagnostic method were described in C. Zhao et al. (2013b).

The simulations were performed at 50-km horizontal resolution, covering China and its surrounding areas with $95 \times 110$ grid cells, as noted in Fig. 1 . The 15 vertical layers from the ground level to the top pressure of $50 \mathrm{hPa}$ were used for all grids. The initial meteorological fields and boundary conditions were from 6-h National Centers for Environmental Prediction (NCEP) reanalysis data with $1^{\circ} \times 1^{\circ}$ spatial resolution. The simulation was conducted for the entire year of 2006, and each run covered $36 \mathrm{~h}$ with a 12 -h spinup time. The outputs from previous runs were used as the initial and boundary conditions for the next run. The domain settings and configuration options are presented in Table 1.

\section{b. Model improvements}

\section{1) SURFACE PARAMETER UPDATES AND DUST SOURCE REGION REDEFINITION IN WRF-CHEM}

As the fundamental interface for land-atmosphere interactions, key land surface parameters, such as land cover and vegetation, directly determine the surface physical properties and in turn modulate the regional exchanges of energy, water, and momentum (Mölders 2001; Pielke 2001). Several outdated surface parameters in WRF were updated, including land cover, green vegetation fraction 
TABLE 1. WRF-Chem configuration options and settings.

\begin{tabular}{lc}
\hline \multicolumn{2}{c}{ Domain setting } \\
\hline $\begin{array}{l}\text { Horizontal grid } \\
\text { Grid spacing }\end{array}$ & $110 \times 95$ \\
Vertical layers & $50 \mathrm{~km} \times 50 \mathrm{~km}$ \\
Projection & 15 \\
\multicolumn{2}{c}{ Lambert conformal conic } \\
Longwave radiation & \\
Shortwave radiation & \\
Cumulus parameterization & RRTMG \\
Land surface & RRTMG \\
Boundary layer & Grell-Deveny \\
Microphysics & Noah \\
photolysis & Yonsei University \\
Gas chemistry & Lin et al. \\
Aerosol chemistry & Fast-J \\
\hline
\end{tabular}

(GVF), and leaf area index (LAI). The standard WRF uses the U.S. Geological Survey (USGS) land-use map derived from normalized difference vegetation index (NDVI) observations spanning April 1992 to March 1993 (Loveland et al. 2000). China has been undergoing great changes in recent decades, such as urbanization, desertification, and deforestation, causing the existing USGS land-use data to become inaccurate (Liu et al. 2005). Consequently, the Moderate Resolution Imaging Spectroradiometer (MODIS) land-use (MCD12Q1) and water mask (MOD44W) data for 2006 (Justice et al. 2002) were collected to produce a new land-use map in our study. GVF has a large impact on the latent heat flux (Chen and Dudhia 2001; Ek et al. 2003). By default, WRF determines GVF based on NDVI observations collected from 1985 to 1990 at a resolution of $20 \mathrm{~km}$ (Gutman and Ignatov 1998). In the present study, the monthly $1-\mathrm{km}$ NDVI product in 2006 (MOD13A2) was used to estimate the GVF. In WRF, LAI is simply calculated using the tabulated value assigned to each vegetation type in conjunction with the GVF. In this study, the modified LAI was directly substituted with 8-day MODIS measurements (MCD15A2) at 1-km resolution for the year 2006 (Knyazikhin et al. 1998). These updated and refined surface parameters could improve the meteorological simulation (Li et al. 2014).

To better characterize the dust emissions, we refined the dust transport model (DUSTRAN) embedded in WRF-Chem, which estimates vertical dust flux based solely on soil type, soil moisture, and vegetation cover (Shaw et al. 2008). In the default WRF-Chem, grids defined as grassland, shrub land, and savanna were assumed erodible surfaces. However, this classification is inadequate, and information on the distribution of dust sources is crucial (Zhang et al. 2003). In our simulation, dust source regions were pinpointed and delineated as four different types (Gobi, sand, loess, and mixed soil, as noted in Fig. S1) based on the Harmonized World Soil Database and MODIS land-use data. Validation of modeled dust emissions is addressed in detail in section 3 .

\section{2) Transition-MEtal-CATAlyzed OXIDATION} OF $\mathrm{SO}_{2}$ AND HETEROGENEOUS REACTIONS

Most current models underestimate global sulfate concentrations, particularly in East Asia (Barrie et al. 2001; Boucher and Pham 2002; Jiang et al. 2013; Myhre et al. 1998; Park et al. 2014). It is suggested that nonphotochemical pathways not included in the models are responsible for this underestimation (Kasibhatla et al. 1997). Several existing observations highlighted the importance of mineral aerosol in sulfate formation. Transition-metal-catalyzed oxidation of $\mathrm{SO}_{2}$ may serve as the dominant pathway of sulfate formation under certain circumstances (Harris et al. 2013). Additionally, mineral cations such as calcium and magnesium tend to neutralize the acidity of aerosol and cloud water (Maxwell-Meier et al. 2004; Cao et al. 2013), further affecting gas-aerosol equilibrium and aqueous chemistry. Furthermore, sulfate-coated dust particles are formed though heterogeneous reactions (Levin et al. 1996; Buseck and Pósfai 1999). These processes, which have not yet been well characterized in the current version of WRF-Chem and most other models, are capable of changing the magnitude and spatial distribution of sulfate and its radiative effect. Here, we improved WRF-Chem to include these processes for the sulfate production. The method is described briefly below, and more details and evaluation can be found in Huang et al. (2014).

Transition metal ions such as Fe(III) and Mn(II) can rapidly oxidize dissolved $\mathrm{S}(\mathrm{IV})$, particularly in the presence of both of them. For typical atmospheric concentrations of iron and manganese, the synergistic effect can raise the catalyzed oxidation rate of S(IV) several times. This has been found through laboratory studies, field measurements, and also numerical simulations (Hoffmann and Jacob 1984; Pandis and Seinfeld 1989; Martin and Good 1991). In this work, the concentrations of $\mathrm{Fe}(\mathrm{III})$ and $\mathrm{Mn}$ (II) were calculated as a product of concentration of mineral aerosol, mass fractions of $\mathrm{Fe}$ and $\mathrm{Mn}$ in mineral aerosol, their solubilities, and valence distributions. Concentrations of mineral aerosol were calculated at each time step in the model. Based on local measurements (Table S1), the mass fractions of Fe and $\mathrm{Mn}$ in mineral aerosol were prescribed as $4.91 \%$ and $0.34 \%$, respectively. The solubilities of $\mathrm{Fe}$ and $\mathrm{Mn}$ were defined as $7 \%$ and $47 \%$, respectively, according to an extensive compilation of solubility measurements (Table S2). Fe(III) was assumed to be $90 \%$ of the dissolved Fe during nighttime and $10 \%$ during daytime because 
iron cycles diurnally (Siefert et al. 1998). All dissolved Mn was assumed to be Mn(II) because dissolved manganese exists mainly as $\mathrm{Mn}(\mathrm{II})$ in the atmospheric water system (Alexander et al. 2009). Modeled atmospheric iron concentrations coincide with corresponding measurements in both spatial distribution and seasonal variation at most monitoring sites like Minqin (Liu et al. 2002), Beijing (P. Zhao et al. 2013), and Shanghai (Ye et al. 2003), as shown in Fig. 2 (the locations of these monitoring stations are shown in Fig. S2). At Qingdao, the model generally underpredicted atmospheric $\mathrm{Fe}$ concentrations. This is likely attributable to the fact that Qingdao's industrial district is about $5 \mathrm{~km}$ north of the sampling site (Hao et al. 2007). To quantify individual and synergistic oxidation in the iron-manganese system in the cloud water, the parameterization proposed by Martin was used in our simulation (Martin and Good 1991).

Mineral aerosol containing alkaline materials such as calcite and dolomite are usually involved in heterogeneous reactions with acid gases [e.g., sulfuric acid $\left(\mathrm{H}_{2} \mathrm{SO}_{4}\right)$ and nitric acid $\left.\left(\mathrm{HNO}_{3}\right)\right]$, which then form nitrate or sulfate (Usher et al. 2003). Once they have acquired hygroscopic nitrate/sulfate coatings, mineral aerosol tend to be more soluble (Wang et al. 2005; Li and Shao 2009). Alkaline mineral cations could neutralize the acidity of the cloud water system, which profoundly affects not only $\mathrm{SO}_{2}$ solubility but also its aqueous oxidation rate. The aqueous-phase acidity is determined by ion balance in WRF-Chem. To better simulate mineral cation concentrations, we estimated the mineral cations according to measurements over China by assuming that $15 \%$ of the mineral aerosol mass is soluble (Table S3). As noted in Fig. S3, the mineral cation concentrations were well reproduced in this simulation.

Mineral aerosol in the atmosphere has high concentrations and are $\mathrm{Al}$ and $\mathrm{Ca}$ rich in China, mainly in the form of aluminium oxide $\left(\mathrm{Al}_{2} \mathrm{O}_{3}\right)$, calcium oxide $(\mathrm{CaO})$, and dolomite $\left[\mathrm{CaMg}\left(\mathrm{CO}_{3}\right)_{2}\right]$ (Winchester et al. 1981; Dai et al. 2010), providing a large surface area for heterogeneous reactions. Previous studies revealed that mineral aerosol enables a reactive uptake of acidic gases such as $\mathrm{SO}_{2}$, dinitrogen pentoxide $\left(\mathrm{N}_{2} \mathrm{O}_{5}\right)$, and $\mathrm{HNO}_{3}$ (Fenter et al. 1995; Goodman et al. 2001; Hanisch and Crowley 2001b; Adams et al. 2005; Johnson et al. 2005; $\mathrm{Li}$ et al. 2006). The first-order uptake parameterization on the surfaces of mineral aerosol shown in Eq. (1) is assumed to quantify the heterogeneous uptake on mineral aerosol surfaces (Dentener et al. 1996; Ullerstam et al. 2003; Fairlie et al. 2010). Heterogeneous reactions of $\mathrm{SO}_{2}, \mathrm{~N}_{2} \mathrm{O}_{5}$, gaseous sulfuric acid, and nitric acid on the surface of mineral aerosol were included in this simulation:

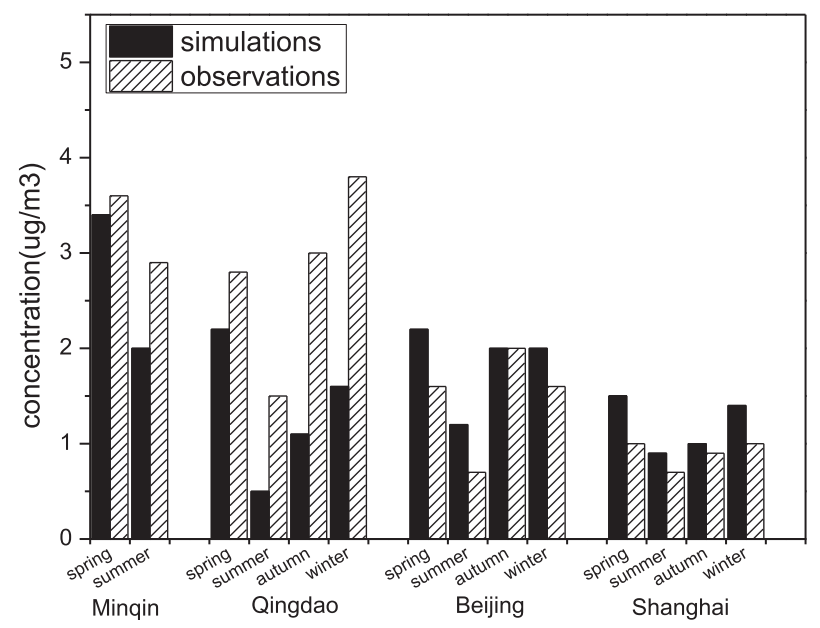

FIG. 2. Comparisons of modeled and observed atmospheric Fe concentrations.

$$
k_{i}=\int_{r 1}^{r 2} 4 \pi r^{2} /\left(\frac{r}{\mathrm{Dg}}+\frac{4}{\nu \gamma}\right) \frac{d N}{d r} d r,
$$

in which $k_{i}$ stands for the apparent rate constant for the size bin $i, N$ is the number concentration of mineral aerosol, Dg is diffusivity $\left(0.15 \mathrm{~cm}^{2} \mathrm{~s}^{-1}\right)$, and $\nu$ is the mean molecular speed $\left(3.0 \times 10^{4} \mathrm{~cm} \mathrm{~s}^{-1}\right)$. Uptake coefficients $\gamma$ were determined by relative humidity (RH) and particulate size. For $\mathrm{SO}_{2}$, we chose uptake coefficients of $1 \times 10^{-4}$ under general conditions and $5 \times$ $10^{-4}$ under high humidity conditions ( $\left.\mathrm{RH}>80 \%\right)$. The uptake coefficients for $\mathrm{H}_{2} \mathrm{SO}_{4}$ under low and high humidity conditions were assigned as 0.05 and 0.1 , respectively. Laboratory studies showed increasing uptake of gaseous nitric acid with the diameters of mineral aerosol (Hanisch and Crowley 2001b; Underwood et al. 2001; Seisel et al. 2004), and we thus assumed the uptake coefficients to be $5.0 \times 10^{-3}$ and $5.0 \times 10^{-2}$ for a small (diameter less than $1 \mu \mathrm{m}$ ) and a large particle, respectively; this value will be doubled under high humidity. The uptake coefficient for $\mathrm{N}_{2} \mathrm{O}_{5}$ was assumed to be the same as that for gaseous nitric acid (Tang et al. 2010).

\section{c. Datasets}

Besides the MODIS datasets described in section 2a, several others were used in this study, including emission inventories and observational data for model evaluation. Typical anthropogenic emissions, including power plant, industrial, residential, and vehicle emissions, were obtained from the Multiresolution Emission Inventory for China (MEIC; see www.meicmodel.org) database (for China) and phase B of the Intercontinental Chemical Transport Experiment (INTEX-B) Asia 
TABLE 2. Primary pollutants and their emission sources in the model.

\begin{tabular}{cccc}
\hline \hline Pollutants & $\begin{array}{c}\text { Typical } \\
\text { anthropogenic } \\
\text { emissions* }\end{array}$ & $\begin{array}{c}\text { Biomass } \\
\text { burning }\end{array}$ & $\begin{array}{c}\text { Natural } \\
\text { emissions }\end{array}$ \\
\hline $\mathrm{SO}_{2}$ & $\sqrt{ }$ & $\sqrt{ }$ & $\times$ \\
$\mathrm{NOx}$ & $\sqrt{ }$ & $\sqrt{ }$ & $\begin{array}{c}\text { Biogenic emissions } \\
\text { Biogenic emissions }\end{array}$ \\
$\mathrm{NO}$ & $\sqrt{ }$ & $\sqrt{ }$ & $\times$ \\
$\mathrm{VOC}$ & $\sqrt{ }$ & $\sqrt{ }$ & Biogenic emissions \\
$\mathrm{CO}$ & $\sqrt{ }$ & $\sqrt{ }$ & $\times$ \\
$\mathrm{PM}$ & $\sqrt{ }$ & $\sqrt{ }$ & Soil-derived dust \\
& $\sqrt{ }$ & $\sqrt{ }$ & Sea salt aerosol \\
$\mathrm{BC}$ & $\sqrt{ }$ & $\sqrt{ }$ & $\times$ \\
$\mathrm{OC}$ & $\sqrt{ }$ & $\sqrt{ }$ & $\times$ \\
\hline
\end{tabular}

* Power plants, residential combustion, industrial process, transportation, and agricultural activities.

emission inventory dataset (for surrounding countries) (Q. Zhang et al. 2009). Anthropogenic emission sources were classified into five sectors: power plants, residential combustion, industrial process, on-road mobile sources, and agricultural activities. Major pollutants, such as $\mathrm{SO}_{2}, \mathrm{NOx}, \mathrm{CO}$, volatile organic compounds (VOC), $\mathrm{NH}_{3}$, particulate matter (PM), BC, and $\mathrm{OC}$, emissions data are included in all five sectors. We updated China's ammonia emission inventory and used it in this simulation (Huang et al. 2012a). Recent studies showed that the ammonia emissions in Huang et al. (2012a) were similar in spatial pattern to the measurements from an infrared atmospheric sounding interferometer (IASI) (Van Damme et al. 2014) and were close to those derived using an inversion of ammonium wet deposition data (Paulot et al. 2014). We prescribed diurnal profiles of industrial, transportation, residential, and power plant emissions following Wang et al. (2010). Hourly variations in $\mathrm{NH}_{3}$ emissions were derived from measurements in Huo et al. (2014). In addition, biomass burning was classified into three subclasses: forest and grass fires, field burning of crop residues, and biofuel combustion. Emissions of major gaseous and particulate pollutants were incorporated in the model. MODIS burned area products (MCD45A1), thermal anomalies/ fire products (MOD/MYD14A1), and statistical data were integrated to estimate emissions. More details were elaborated in our previous publications (Song et al. 2010; Huang et al. 2012b,c). The primary species emissions in the model and their anthropogenic/natural sources are listed in Table 2.

The China Atmosphere Watch Network (CAWNET) conducted in situ measurements of daily mean $\mathrm{PM}_{10}$ compositions at 14 stations across China for the entire year of 2006 (locations are marked in Fig. S2) using the $\mathrm{X}$-ray fluorescence method and ion chromatography
TABLE 3. Statistical analyses of the simulated meteorological variables vs the ground observations. MB and RMSE refer to mean bias and root-mean-square error respectively.

\begin{tabular}{llcc}
\hline \hline & Index* & 2-m temperature $\left({ }^{\circ} \mathrm{C}\right)$ & $\begin{array}{c}\text { 2-m relative } \\
\text { humidity }(\%)\end{array}$ \\
\hline Winter & MB & -0.73 & 0.82 \\
& RMSE & 1.80 & 10.00 \\
Spring & MB & -0.54 & -0.80 \\
& RMSE & 1.66 & 10.12 \\
\multirow{4}{*}{ Autummer } & MB & -0.55 & 0.70 \\
& RMSE & 1.55 & 9.37 \\
& MB & -0.63 & 3.12 \\
& RMSE & 1.60 & 10.10 \\
\hline
\end{tabular}

(X. Zhang et al. 2012). CAWNET observations of sulfate, nitrate, ammonium, $\mathrm{BC}, \mathrm{OC}$, and mineral aerosol concentrations were used to evaluate corresponding simulation results. To verify the modeled dust emissions, we conducted measurements of the 10-min accumulated mass concentration of $\mathrm{PM}_{10}$ using a beta gauge (FH62$\mathrm{C} 14$, Thermo) at Duolun $\left(42^{\circ} 21^{\prime} \mathrm{N}, 116^{\circ} 31^{\prime} \mathrm{E}\right)$ and Yulin $\left(38^{\circ} 18^{\prime} \mathrm{N}, 109^{\circ} 46^{\prime} \mathrm{E}\right)$ in April 2006 , both of which are located in typical dusty regions.

\section{Results and discussions}

\section{a. Model evaluation}

Meteorological conditions play an important part in aerosol transport, diffusion, and chemical reactions in the atmosphere. Simulated meteorological field conditions were evaluated using daily temperature and relative humidity observations available from the China Meteorological Data (http://cdc.cma.gov.cn), recorded at $2 \mathrm{~m}$ above ground level (T2 and RH2) at 839 stations. Simulated results are compared with observations in terms of performance statistics in Table 3, including mean bias (MB) and root-mean-square error (RMSE). Generally, the model well reproduced both temporal variations and spatial distributions of $\mathrm{T} 2$ and $\mathrm{RH} 2$. Although the temperature was underpredicted by $0.7^{\circ} \mathrm{C}$ in winter, biases were smaller in the other three seasons $\left(-0.5^{\circ} \sim-0.6^{\circ} \mathrm{C}\right)$. The mean biases of simulated $\mathrm{RH} 2$ were less than $\pm 4 \%$ in the four seasons. The RMSE of $\mathrm{RH} 2$ ranged from $9 \%$ to $11 \%$, with better predictions in summer. Influenced by Siberian air masses in winter, northern China is much colder than the southern part; the temperature gaps were much less significant in summer. In terms of $\mathrm{RH} 2$, the relative humidity tended to be highest in summer, at $60 \%-90 \%$ nationwide, except for Inner Mongolia and Xinjiang Province; it decreased to its minimum in spring, with more moderate values in winter and autumn. The model tended to underestimate $\mathrm{RH} 2$ in northern China. The observed and simulated RH2 at six sites are compared in Fig. S4. At 

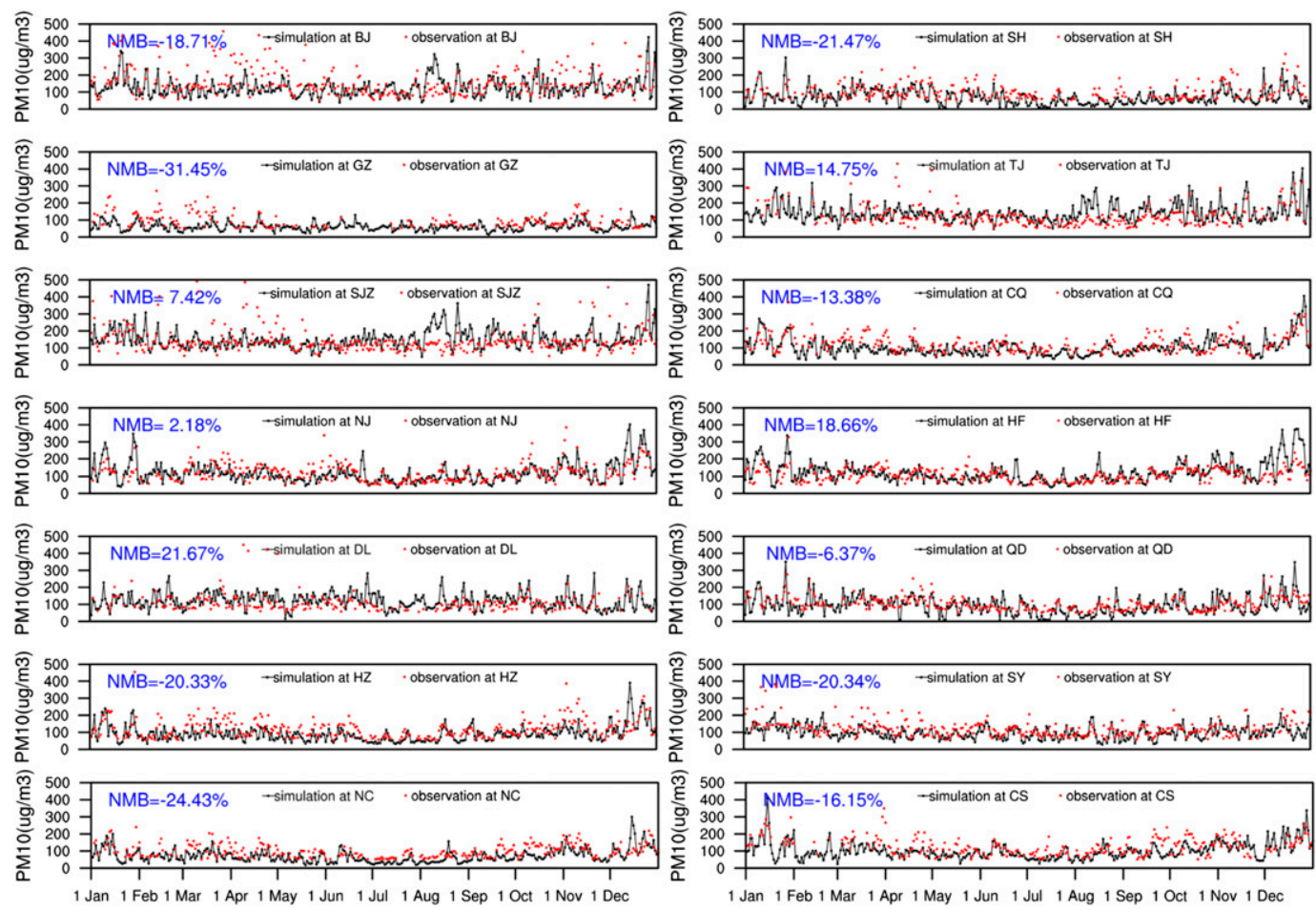

FIG. 3. Time series of the daily mean observed and simulated $\mathrm{PM}_{10}$ at 14 cities (observations are marked with red dots, and model results are plotted in black lines). NMB represents the normalized mean bias: Beijing (BJ); Shanghai (SH); Guangzhou (GZ); Tianjin (TJ); Shijiazhuang (SJZ); Chongqing (CQ); Nanjing (NJ); Hefei (HF); Dalian (DL); Qingdao (QD); Hangzhou (HZ); Shenyang (SY); Nanchang (NC); and Changsha (CS).

the Nanning, Panyu, Jinsha, and Taiyangshan sites, which are located in southern and central China, the MBs of simulated RH2 were within $\pm 4.0 \%$. However, the MBs of simulated $\mathrm{RH} 2$ at Xian and Zhengzhou (northern stations) were as high as $-10.6 \%$ and $-13.9 \%$, respectively. The MBs reached $-11.3 \%$ and $-16.0 \%$, respectively, in winter, which might result from the overestimated temperature.

Figure 3 shows the time series of the daily averages of observed and simulated $\mathrm{PM}_{10}$ concentrations at 14 cities across China in 2006. Observed $\mathrm{PM}_{10}$ concentrations ranged from 52 to over $500 \mu \mathrm{g} \mathrm{m}^{-3}$, and the normalized mean biases $(\mathrm{NMB})$ of simulations were within $\pm 30 \%$. Among three megacities, Beijing suffered the most serious $\mathrm{PM}_{10}$ pollution, with an annual-mean concentration of $172 \mu \mathrm{g} \mathrm{m}^{-3}$, which was 67 and $72 \mu \mathrm{g} \mathrm{m}^{-3}$ higher than those in Shanghai and Guangzhou, respectively. North China (NC; outlined in Fig. 1), which has a concentrated dense population and many industrial plants, is the most polluted region. Influenced by massive residential and industrial emissions (Fig. S5), northern cities like Beijing and Shijiazhuang experienced high $\mathrm{PM}_{10}$ concentrations, above $150 \mu \mathrm{g} \mathrm{m}^{-3}$ year-round. During the period from November 2005 to February of 2006, concentrations frequently exceeded $400 \mu \mathrm{g} \mathrm{m}^{-3}$. This was ascribed to intensified combustion-induced emissions with increasing heating demand, coupled with the low planetary boundary layer height (PBLH) in winter. In spring, NC was often influenced by dust storms transported from the northwestern dust source regions. Thus, $\mathrm{PM}_{10}$ mass concentrations over Beijing and Shijiazhuang increased to over $300 \mu \mathrm{g} \mathrm{m}^{-3}$ from time to time. The pollution was alleviated in summer because of high PBLH and plenty of precipitation (Fig. S6), together with the relative absence of heating-induced emissions. Chongqing in the Sichuan basin (SB) also experienced severe $\mathrm{PM}_{10}$ pollution, with annual average mass concentration exceeding $130 \mu \mathrm{g} \mathrm{m}^{-3}$. In addition to dense emissions, frequent temperature inversion and high humidity also played major roles in causing the heavily polluted conditions (Yang et al. 2011). South China (SC), by contrast, was less polluted. The annualmean $\mathrm{PM}_{10}$ concentrations in Guangzhou and Nanchang were approximately $100 \mu \mathrm{g} \mathrm{m}^{-3}$. In addition to lower emissions, frequent rainfall also facilitated the scavenging of ambient particles.

Seasonal distributions of simulated surface mass concentrations of different aerosol components in $\mathrm{PM}_{10}$ in 2006 are displayed in Fig. S7, including sulfate, nitrate, ammonium, mineral aerosol (both natural and anthropogenic 
TABLE 4. Comparisons of modeled and observed annual-mean mass concentrations of different chemical compositions in $\mathrm{PM}_{2.5}$ $\left(\mu \mathrm{g} \mathrm{m}^{-3}\right)$. Observations are from Hagler et al. (2006), Cao et al. (2009), Yang et al. (2011), and Yang et al. (2012). Values out of the parentheses are observations, and those in the parentheses represent the corresponding model results.

\begin{tabular}{|c|c|c|c|c|c|c|}
\hline Location & Period & Sulfate & Nitrate & Ammonium & $\mathrm{BC}$ & $\mathrm{OC}$ \\
\hline Guangzhou & $2002 / 03$ & $14.7(15.8)$ & $4.0(5.3)$ & $4.5(5.2)$ & $4.4(3.2)$ & $24.6(7.0)$ \\
\hline Beijing & $2005 / 06$ & $15.8(17.8)$ & $10.1(10.7)$ & $7.3(8.8)$ & $8.2(4.2)$ & $24.5(8.7)$ \\
\hline Chongqing & $2005 / 06$ & $25.6(28.0)$ & $5.5(4.3)$ & $7.9(9.4)$ & $6.5(4.4)$ & $16.8(13.0)$ \\
\hline Hangzhou & $2001 / 02$ & $20.1(21.3)$ & $7.1(8.7)$ & $7.0(8.3)$ & $4.0(3.7)$ & $21.4(6.2)$ \\
\hline Jinan & $2006 / 07$ & $30.9(23.6)$ & $10.6(15.0)$ & $14(12.5)$ & $4.1(4.9)$ & $35.7(13.7)$ \\
\hline
\end{tabular}

emissions), OC, and BC. Observations of annual-mean mass concentrations of different chemical compositions in $\mathrm{PM}_{2.5}$ from 2001 to 2007 are compared with modeled corresponding values in Table 4 based on previous publications. Because China's emissions continually increased during 2000 to 2006 ( $\mathrm{Lu}$ et al. 2010), the observations in earlier years may be lower than those in 2006. To further verify our simulation, we introduced ambient $\mathrm{PM}_{10}$ composition measurements at 14 sites from CAWNET, in which 24-h aerosol samples were collected and analyzed every 3 days (X. Zhang et al. 2012). In Fig. 4, modeled daily averages of different components were compared with the corresponding measurements.

Sulfate is an important constituent of aerosols, mainly generated from chemical reactions of gas-phase precursors $\left(\mathrm{SO}_{2}\right)$ through three pathways: gaseous photochemical reactions with the hydroxyl $(\mathrm{OH})$ radical; aqueous oxidation by dissolved hydrogen peroxide $\left(\mathrm{H}_{2} \mathrm{O}_{2}\right)$, ozone $\left(\mathrm{O}_{3}\right)$, and transition-metal-catalyzed oxidation; and heterogeneous reactions with mineral aerosol (Usher et al. 2002; Ullerstam et al. 2003; Seinfeld and Pandis 2006). All these pathways were taken into account in this modified model. This revised model presents a better performance compared with the default version (Fig. S8) as well with previous simulations (Wang et al. 2013). We found that mineral aerosol led to faster $\mathrm{SO}_{2}$ oxidation through three pathways: First, more $\mathrm{SO}_{2}$ was dissolved as the cloud water alkalinity increased due to water-soluble mineral cations, and then sulfate production was enhanced through aqueousphase oxidation of dissolved S(IV), contributing 5\% to national sulfate production. Second, sulfate was enhanced through S(IV) catalyzed oxidation in aqueous solution by transition metals, adding approximately $8 \%$ of the annual sulfate production. Third, $\mathrm{SO}_{2}$ can react on the surface of mineral aerosol to produce sulfate, a process that contributed approximately $9 \%$ of the national average sulfate concentration. Overall, mineral aerosol contributed about $22 \%$ of sulfate production nationwide on average in 2006. It increased the national mean sulfate concentration by approximately $2 \mu \mathrm{g} \mathrm{m}^{-3}$.
The NMBs of simulated daily mean concentrations, shown in Fig. 4, were $-36.0 \%,-34.6 \%,-19.2 \%$, and $-23.8 \%$ in winter, spring, summer, and autumn, respectively. Model results had low biases when the observed concentrations were extremely high. For instance, at Xian and Zhengzhou, high sulfate concentrations exceeding $50 \mu \mathrm{g} \mathrm{m}^{-3}$ were often caused by local emissions in winter. The model with $50-\mathrm{km}$ spatial resolution demonstrated poor performance in capturing the high concentrations during these local pollution episodes. Spatially, observed sulfate concentrations were higher at Zhengzhou and Chengdu, with annualmean concentrations of 43.9 and $42.5 \mu \mathrm{g} \mathrm{m}^{-3}$, respectively. Modeled sulfate displayed similar distributions, concentrated in the SB and NC. In NC, both simulations and observations showed higher sulfate concentrations in winter and summer. In winter, emissions were more intensive because of the heating demand, weak vertical turbulence, and less rainfall, which led to accumulating sulfate. During the summertime, high temperature, high humidity, and elevated atmospheric oxidation capacity (higher summer $\mathrm{O}_{3}$ concentration in Fig. S6) favored sulfate formation (Yang et al. 2011). In the SB, dense $\mathrm{SO}_{2}$ emissions, stagnant meteorological conditions, high ambient temperatures, and relative humidity favored the formation and accumulation of sulfate all year-round (Q. Zhao et al. 2010). The heavier load of sulfate in winter was attributed to a combination of elevated emissions from residential combustion for heating and the reduced dilution and dispersion of pollutants. Compared with the SB and NC, SC was less polluted with sulfate. In SC, sulfate concentration peaked in autumn because of the lower precipitation and higher ozone concentration (Zheng et al. 2010; Tao et al. 2012).

Nitrate, as another principal secondary inorganic aerosol, is formed by photochemical oxidation of nitric oxide and the following phase equilibrium of nitric acid. As displayed in Fig. 4, the NMBs of simulated daily mean concentrations were $-22.3 \%,-49.8 \%,-27.6 \%$, and $-29.7 \%$ in winter, spring, summer, and autumn, respectively. Higher nitrate concentrations were observed at Zhengzhou and Gucheng, with annual-mean 


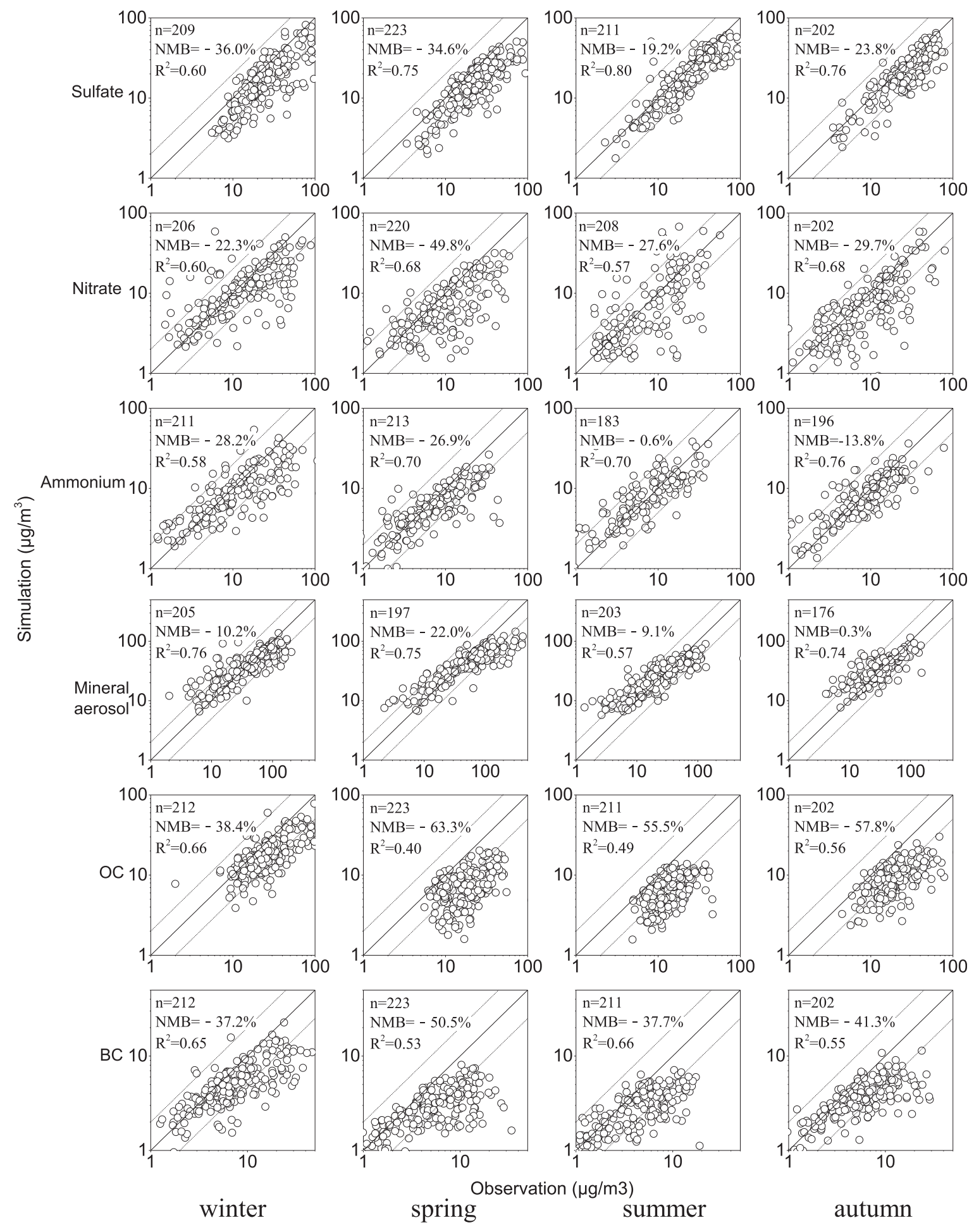

FIG. 4. Scatterplots of daily measurements of sulfate, nitrate, ammonium, mineral aerosol, OC, and BC concentrations in $\mathrm{PM}_{10}$, and the corresponding WRF-Chem simulations in 2006. Number of samples $(n)$, NMB, and the square of correlation coefficient $\left(R^{2}\right)$ are given in each scatterplot. The solid 1:1 lines and dashed 1:2 and 2:1 lines are shown for reference. 
concentrations of 23.9 and $22.5 \mu \mathrm{g} \mathrm{m}^{-3}$, respectively. Similar to the observations, modeled nitrate concentrations were mostly concentrated in NC. Nitrate concentration presented a distinct seasonal pattern, increasing to its maximum in winter. On the one hand, combustion-induced NOx emissions were enhanced because of the heating demand in winter, and on the other hand, the equilibrium relationship between gaseous nitric acid and particulate nitrate was also responsible for this seasonal pattern (Stelson et al. 1979). In contrast, the concentrations of nitrate in summer were much lower because of the higher PBLH and stronger wet scavenging, together with enhanced conversion to gaseous nitric acid because of higher temperatures. Our model showed weaker ability in reproducing nitrate in spring, with a NMB of $-49.8 \%$. This discrepancy may be attributable to the interaction between gaseous nitric acid and mineral aerosol that has been found in both field and laboratory experiments (Hanisch and Crowley 2001a; Underwood et al. 2001; Seisel et al.2004). We have included the uptake effects of gaseous $\mathrm{HNO}_{3}$ and $\mathrm{N}_{2} \mathrm{O}_{5}$ on the surfaces of mineral aerosol. However, measured uptake coefficients still have great uncertainties, as shown in Table S4. More measurements are urgently needed, and better parameterization of these heterogeneous reactions will be essential. Underestimated mineral aerosol in spring was probably another cause for nitrate underestimation. Additionally, several observation sites were located near cities (such as Xian and Chengdu), whereas the simulation results are at $50-\mathrm{km}$ resolution. Combined with the uncertainties in NOx emission estimation, the low bias of modeled nitrate are explainable.

As one of the most important cations, ammonium is often associated with nitrate and sulfate. It is first neutralized by sulfuric acid to form ammonium sulfate or ammonium bisulfate, and excess gaseous ammonia could react with nitric acid to form ammonium nitrate (Ansari and Pandis 1998; Mathur and Dennis 2003). The model captured the spatiotemporal distribution of observed ammonium. The NMBs of simulated daily mean concentrations in four seasons were all within $30 \%$. Both observations and simulations indicated that ammonium was mainly located in $\mathrm{NC}$ and $\mathrm{SC}$. $\mathrm{NH}_{3}$, as ammonium's precursor, is overwhelmingly emitted from fertilization and livestock waste in China, with the biggest emission intensities in NC and the SB (Huang et al. 2012a). Simultaneously, sulfate and nitrate concentrations were also higher in NC and the SB. Hence, ammonium concentration was greatly elevated in these two regions. In NC, ammonium had two peaks: one in summer because of the highest sulfate concentrations and one in winter as a consequence of increasing nitrate concentrations. In the SB, ammonium showed smaller seasonal fluctuation because of the steadily abundant sulfate.

Ambient OC derives from both primary sources and secondary production. Residential combustion, which releases $2.6 \mathrm{Tg}$ OC every year and accounts for $82 \%$ of total emissions, dominated in China's OC emission (Lei et al. 2011). Spatially, OC distribution was consistent with residential sources, which were mainly concentrated in $\mathrm{NC}$ and the SB. In winter, OC was underestimated by the model, with a NMB of $-38.4 \%$. This negative bias became increasingly large in other seasons. The model results showed that the NMBs of simulated daily mean concentrations exceeded $-50 \%$ in spring, summer, and autumn. It has been found that the SOA production in the current version of WRF-Chem is significantly underestimated if the volatility basis set (VBS) approach is not used (Shrivastava et al. 2011, 2013). The gap between observations and simulations was great in spring and summer, when photochemistry was active and biogenic VOC emissions rise (Li et al. 2012). Based on in situ, semicontinuous OC analysis in Beijing, SOC contributes $45 \%$ to $\mathrm{OC}$ concentrations in summer; this proportion decreases to $19 \%$ in winter (Lin et al. 2009), consistent with the seasonal pattern of OC bias in this simulation. SOC formation is a complex process and is not yet sufficiently understood (Kanakidou et al. 2005). Limited understanding on SOC brings uncertainties related to the relevant, oversimplified parameterizations used in the chemical transport and climate models.

China's huge consumption of coal and biofuels is primarily responsible for high $\mathrm{BC}$ concentration. The NMBs of simulated daily mean concentrations ranged from $-37.2 \%$ to $-50.5 \%$ in different seasons. Spatially, $\mathrm{BC}$ emissions are primarily distributed in NC, where the use of raw coal and biofuels for cooking and heating is a widespread practice (Streets et al. 2001). Both observed and modeled BC concentrations reached their maxima in winter and dropped to their lowest levels in summer. In winter, BC was more likely to accumulate locally because of weak vertical turbulence and reduced rainfall (Fig. S6). Additionally, more emissions due to domestic heating increased BC pollution in winter. Modeled BC concentrations were lower than observations where BC concentrations were extremely high, such as at Xian and Chengdu. It was partially caused by homogeneity in the $50-\mathrm{km}$ model grid. It is also noteworthy that significant uncertainty still exists in China's BC emission inventory. Carmichael et al. (2003) pointed out that BC levels were systematically underpredicted in China; Clarke et al. (2004) concluded that BC emissions from combustion sources north of $25^{\circ} \mathrm{N}$ were underestimated by a factor of 3 . Residential emission has been identified as a major cause for uncertainty because of the 

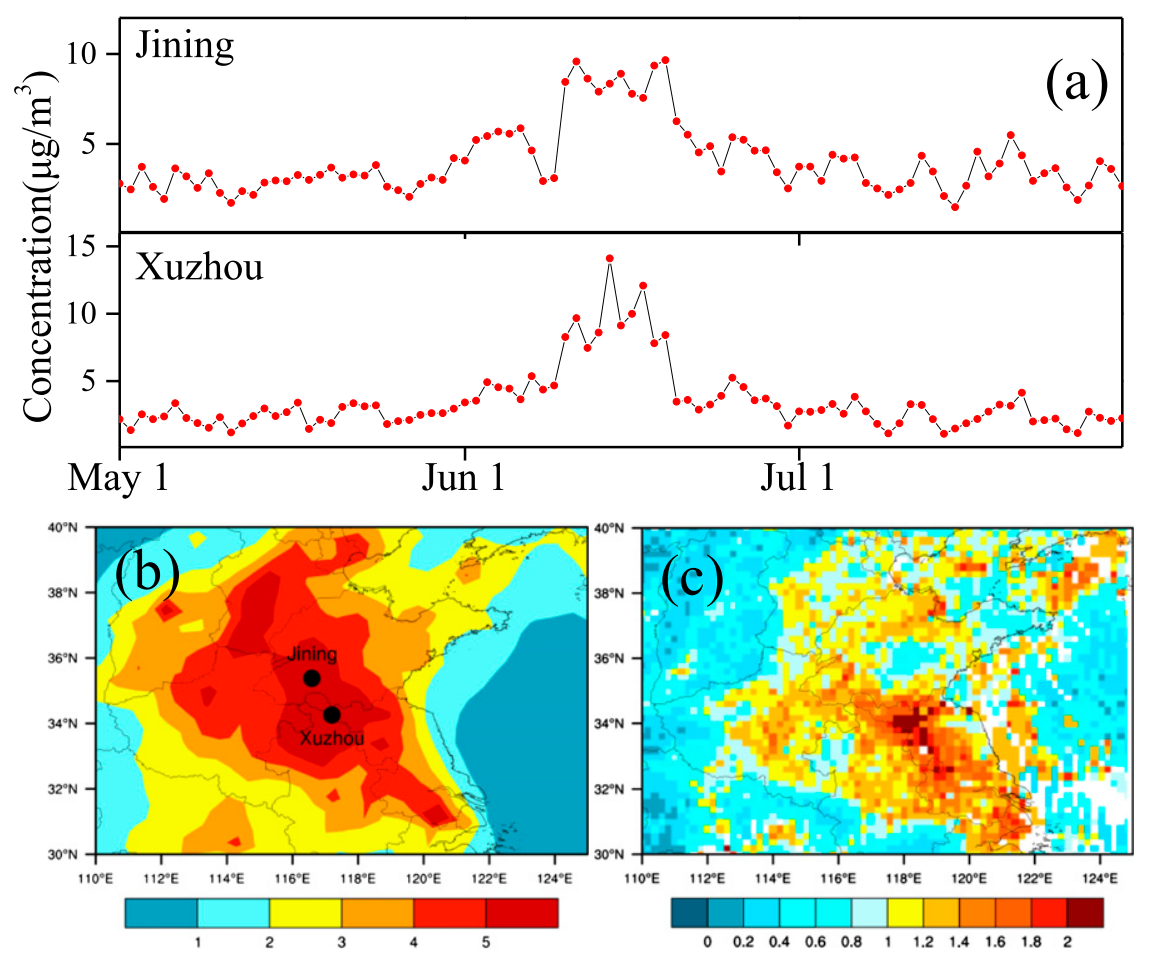

FIG. 5. (a) Temporal variations in BC concentrations at Jining and Xuzhou during the period from May to July, (b) spatial distribution of BC concentration in $\mu \mathrm{g} \mathrm{m}^{-3}$, and (c) $550-\mathrm{nm}$ aerosol optical thickness observations from MODIS in mid-June.

lack of reliable statistics and local emission factor measurements (Q. Zhang et al. 2009). Moreover, the temporal variation in residential combustion for heating is so highly temperature dependent that it is hard to reproduce it well in the model.

A spike of simulated $\mathrm{BC}$ concentration was found in NC during mid-June, which was attributed to field burning of crop straw, a widespread practice in agricultural regions to control weeds, reduce pests, and clear land inexpensively. Crop residue burning in June emitted a total of $17 \mathrm{Gg} \mathrm{BC}$, a major combustion product, into the atmosphere, not only rapidly degrading the local air quality but also affecting the tropospheric chemistry, threatening public health, and contributing to climate change (Huang et al. 2012c). We included a high-resolution emission inventory of crop residue field burning in this simulation (section 2c). As shown in Fig. 5a, BC concentrations at Xuzhou and Jining increased sharply in mid-June of 2006, doubling or even tripling compared with the corresponding concentrations in May and July. Crop fire detections were most intense in eastern Henan, southern Shandong, northern Anhui, and northern Jiangsu Provinces according to MODIS thermal anomalies/fire products (Huang et al. 2012c). In Fig. 5b, the modeled BC concentrations coincided with patterns of crop fires. Similar distributions were also detected by MODIS optical depth observation in mid-June, as noted in Fig. 5c.

Emissions of mineral aerosol are huge in China. Northern China, covering many deserts, including the Gobi Desert, and arid loess lands, is a large dust source (Zhang et al. 1997). Furthermore, anthropogenic activities greatly contribute to ambient mineral aerosol, including power plants and industrial boilers, the cement industry, and the iron and steel industries (Lei et al. 2011). Both natural and anthropogenic sources were taken into account. Simulated mineral aerosol concentrations are compared with measurements in Fig. 4, and they are comparable in both magnitude and seasonal patterns. The NMBs of simulated daily mean concentrations were $-10.2 \%,-22.0 \%,-9.1 \%$, and $0.3 \%$ in winter, spring, summer, and autumn, respectively. Without considering emissions from construction operations and unpaved roads, mineral aerosol concentrations were underestimated, especially in spring. Dust regions are predominately concentrated in NC, specifically, Inner Mongolia, Xinjiang, and Gansu Provinces (Fig. S1). Meanwhile, anthropogenic sources such as industrial manufactures and power plants are relatively denser in Hebei, Shandong, and Henan Provinces (Q. Zhang et al. 2009). Consequently, NC suffered from more grievous pollution of mineral aerosol than did the 

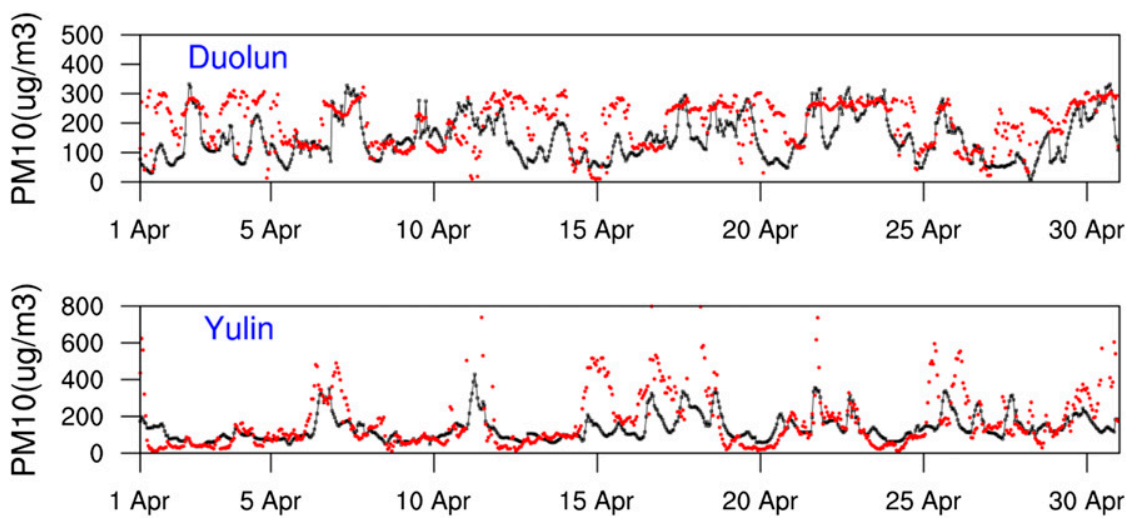

FIG. 6. Time series of modeled (black lines) and measured (red dots) hourly $\mathrm{PM}_{10}$ concentrations at Duolun and Yulin in April 2006.

southern part of the nation. Seasonally, mineral aerosol peaked in winter and spring in $\mathrm{NC}$ but fluctuated less in southern regions. The disparity was mainly caused by meteorology-dependent dust emission and varied heating demand. Spring is the worst dust-emitting season with half of the annual emission amount (Xuan and Sokolik 2002). Thus, mineral aerosol concentration reached its maximum in $\mathrm{NC}$, where the impact of dust emission was remarkable. In winter, intensified emissions and unfavorable diffusion conditions resulted in concentrated mineral aerosol in NC (Zhao et al. 2006). These two factors were far less significant in the southern part.

To verify the modeled dust emissions, the mass concentration of particles with diameters less than $10 \mu \mathrm{m}$ was measured at Duolun and Yulin in April 2006 (section 2c). These two sites, which feature a large-scale desert and a sparse population, are located in Inner Mongolia and Shaanxi Province. Soil-derived dust emission is the predominant source of particles there. Hourly $\mathrm{PM}_{10}$ concentrations in April at these two stations are shown with red dots, and the corresponding simulation results are plotted as black lines in Fig. 6. The monthly averaged $\mathrm{PM}_{10}$ concentration at Duolun was $199 \mu \mathrm{g} \mathrm{m}^{-3}$, with the maximum of $322 \mu \mathrm{g} \mathrm{m}^{-3}$ on 7 April. High concentrations above $200 \mu \mathrm{g} \mathrm{m}^{-3}$ were observed over half of the month. Eight dust events throughout April were captured by our model, but the observed peak values on 4 and 13-15 April were slightly underestimated. At Yulin, dust events were less frequent but had higher peak concentrations, over $500 \mu \mathrm{g} \mathrm{m}^{-3}$. Strong dust storms occurred on 6, 11, 15-18, and 26 April. The model captured almost all the dust events but underpredicted the peak values.

\section{b. Aerosol optical depth and absorption AOD}

WRF-Chem computes aerosol optical properties at the four wavelengths $(300,400,600$, and $1000 \mathrm{~nm})$ for shortwave. To obtain the aerosol optical depth (AOD) at 550 and $670 \mathrm{~nm}$ that are retrieved from satellite and ground observations, linear interpolations were used here (Nordmann et al. 2014). Seasonal modeled 550-nm AOD results display a pattern similar to 550-nm AOD observations by MODIS (MOD08 L3) in Fig. S9. AOD varied in both space and time. Spatially, higher AOD was concentrated in the North China Plain, the middle and lower reaches of the Yangtze River, and the Sichuan basin. Both the model and remote sensing illustrated that AOD was significantly elevated in summer over the North China Plain. This coincides with the aforementioned sulfate and ammonium concentration peaks in summer. Furthermore, higher relative humidity in summer favors the hygroscopic growth of aerosols. Additionally, high PBLH in summer was associated with increased AOD in the North China Plain. Over the SB, AOD exceeded 0.6 all year-round. As mentioned previously, specific meteorological conditions like weak wind and high humidity facilitate the formation and accumulation of aerosols. The model underestimated the AOD in northwest China, specifically in the proximity of the Taklamakan Desert. It can be explained by the fact that the model tended to underpredict the dust emissions during large dust storms, as stated in section $3 a$.

The Aerosol Robotic Network (AERONET) has $\sim 100$ identical, globally distributed sun- and sky-scanning ground-based automated radiometers, which provide measurements of aerosol optical properties throughout the world (Holben et al. 2001). Here, available AERONET measured 670-nm AOD at three sites (Beijing, $40.0^{\circ} \mathrm{N}$, $116.4^{\circ} \mathrm{E}$; Taihu, $31.4^{\circ} \mathrm{N}, 120.2^{\circ} \mathrm{E}$; and Hong Kong, $22.3^{\circ} \mathrm{N}$, $114.2^{\circ} \mathrm{E}$ ) that were compared with modeled daytime AOD. Additionally, AOD retrieved from MODIS at $550 \mathrm{~nm}$ was also used to evaluate the modeling results for the entire year of 2006 (Hsu et al. 2006). Daily AOD values from three datasets are compared in Fig. 7. This 

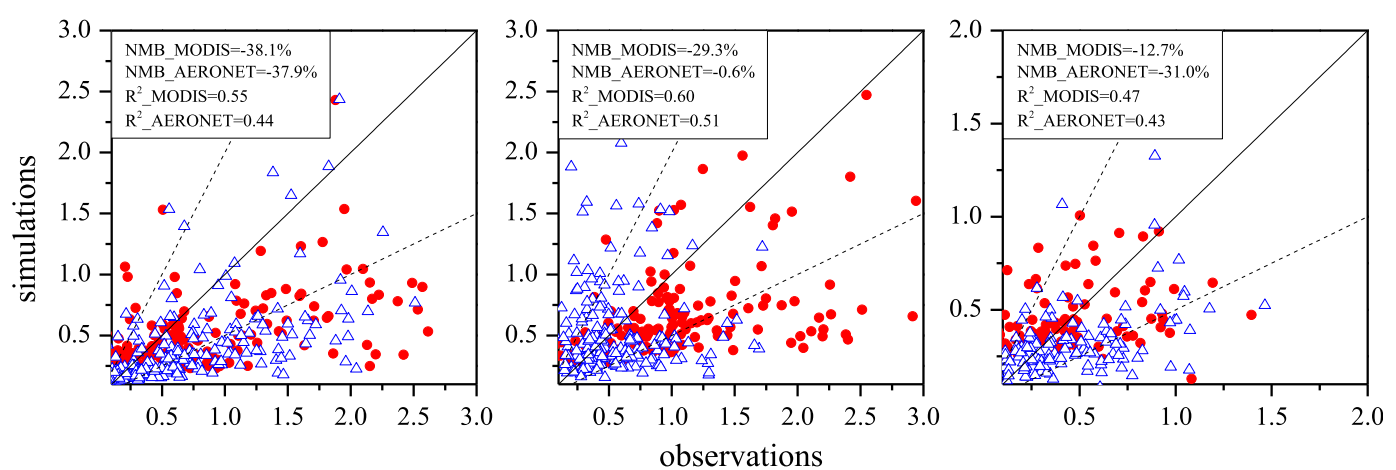

FIG. 7. Scatterplots of simulated daily AOD values and corresponding observations at three AERONET sites (blue triangles), and the corresponding MODIS AOD (red dots) in 2006. The solid 1:1 lines and dashed 1:2 and 2:1 lines are shown for reference. NMB and the square of correlation coefficient $\left(R^{2}\right)$ are given in each scatterplot.

simulation was comparable to ground-based observations in magnitude, with a NMB of $-33.6 \%$, but MODIS retrieval exhibited a systematically high bias at Beijing. Among the three sites, Beijing was continuously covered by the highest AOD according to ground-based observations, remote sensing, and numerical simulation. High AOD values in January, April, and July were attributed to severe haze events in winter, dust storms in spring, and elevated sulfate and ammonium concentration in summer, as discussed in section 3a. However, the model trended with a low bias in spring due to underpredicted dust concentrations. The seasonal variations in modeled and AERONET-observed SSA are shown in Table 5. Apparently, SSA exhibited a weak seasonal cycle at Beijing, with large values occurring during the summer and smaller values occurring in winter. The relatively smaller value of SSA in winter coincided with sharply increased residential combustion and $\mathrm{BC}$ emissions that ensued (Kim et al. 2004). The Taihu site is located on the northern edge of Tai Lake, which is the third largest freshwater lake in China. Surrounded by several large cities in the Yangtze delta, this site is dominated by the presence of industrial aerosols. AOD frequently exceeded 1.5 during the summer season. The maximum AOD in summer may be related to weather patterns. Because cold air is more active in autumn and winter in the lower Yangtze River delta region, the strong winds accelerated the diffusion of pollutants, leading to smaller aerosol optical depth (Pan et al. 2010). Despite the considerable negative biases of modeled SSA at Taihu station in Table 5, the model captured observed seasonal variations, with summer maxima and winter minima. Presumably, the underestimation can be attributed to the model's assumption of internally mixed aerosols, which may overly amplify aerosol absorption (Bond et al. 2006). The site at Hong Kong Polytechnic University is in the center of Hong Kong. It is affected by perpetual anthropogenic pollution along with sea salts carried in by the sea breeze. The observed, annual-mean AOD value was 0.54 at the Hong Kong site, slightly lower than 0.64 estimated by the model. However, some discrepancies were found in winter and spring SSA between the simulation and measurements. These may have been because of the biomass burning in Vietnam, Thailand, and Myanmar, which emits a tremendous amount of BC particles, strongly affects Hong Kong (Park et al. 2011), and mainly occurs outside the modeling domain.

Aerosol extinction vertical profiles play an important part in determining the sign and magnitude of DRE (Samset et al. 2013). To evaluate modeled extinction vertical distribution, we collected Cloud-Aerosol Lidar and Infrared Pathfinder Satellite Observations (CALIPSO) 532-nm extinction profiles (June 2006-June 2007) and compared them with simulated results in three typical regions. It is illustrated in Fig. 8 that high aerosol extinction was confined to the first few kilometers. In winter, the extinction value near the surface is shown to be the largest and then decreases rapidly with altitude above $1 \mathrm{~km}$. In spring and summer, aerosol extinction was still high around $1.0 \mathrm{~km}$. Higher extinctions at higher levels in spring and summer due to stronger vertical transport than in autumn and winter were captured by the model in general, implying that the critical processes (such as dynamical transport, chemistry, microphysics, wet scavenging, etc.) that control the vertical profiles of aerosol extinction were probably represented well in the model. In the SB, with dense anthropogenic emissions,

TABLE 5. Comparisons of modeled and observed seasonal-mean SSA. Values out of the parentheses are observations, and those in the parentheses represent the corresponding model results.

\begin{tabular}{lcccc}
\hline & Winter & Spring & Summer & Autumn \\
\hline BJ & $0.881(0.883)$ & $0.913(0.889)$ & $0.921(0.906)$ & $0.882(0.888)$ \\
TH & $0.921(0.900)$ & $0.935(0.902)$ & $0.951(0.910)$ & $0.936(0.903)$ \\
HK & $0.852(0.882)$ & $0.804(0.890)$ & $-(0.912)$ & $0.908(0.909)$ \\
\hline
\end{tabular}




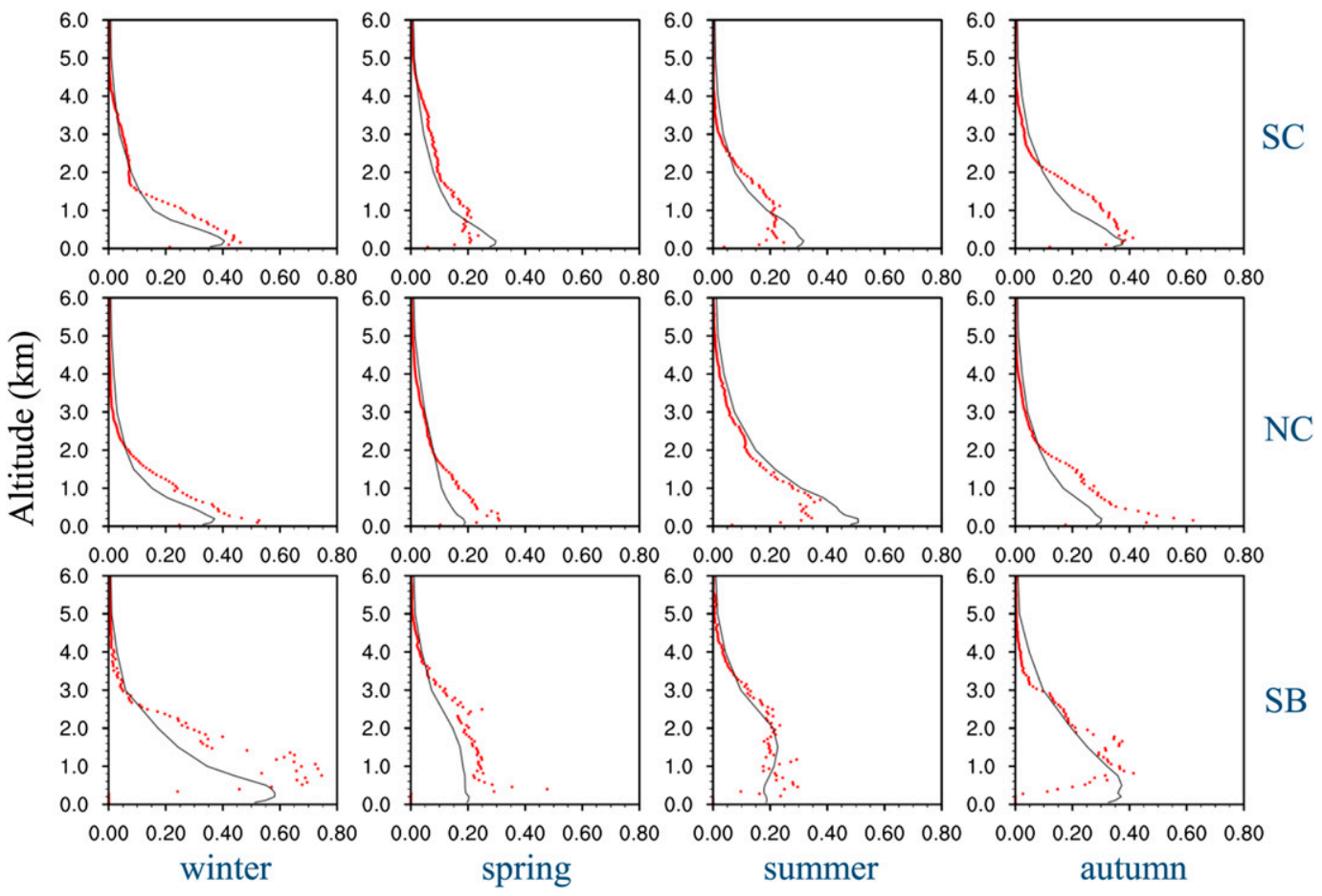

FIG. 8. Comparison of modeled seasonal average 532-nm extinction (solid black lines) and corresponding CALIPSO observations (red dots) for three different regions: SC, NC, and the SB.

aerosol extinction generally exceeded $0.2 \mathrm{~km}^{-1}$ below $2 \mathrm{~km}$. In winter, extinction was as high as $0.5 \mathrm{~km}^{-1}$ in the near-surface layer and decreased rapidly with height above $1 \mathrm{~km}$. As mentioned in section $3 \mathrm{a}$, in the SB, PBLHs were extremely low in winter, which hindered the vertical transport of aerosols. By contrast, enhanced convection in summer kept aerosol extinction high above $2 \mathrm{~km}$. The model underestimated the extinction peak between 2 and $3 \mathrm{~km}$ in spring, most likely because of the underprediction of dust transport. In NC, simulated extinction is slightly lower than observed except in summer, which probably results from the underestimated aerosol concentrations. Nonetheless, the model successfully reproduced the seasonal pattern observed by CALIPSO, for instance, a more distinct quasi-exponential shape in winter than in spring or summer. In SC, modeled aerosol extinction generally coincided with satellite retrievals. High extinctions were concentrated below $2 \mathrm{~km}$, particularly obvious in winter and autumn.

The spatial distributions of annual, average 600-nm AOD and absorption AOD (AAOD) from the WRFChem simulation are shown in Figs. 9a and 9b. Both AOD and AAOD were much larger over the NC and the $\mathrm{SB}$, consistent with the distribution of aerosol mass (a)

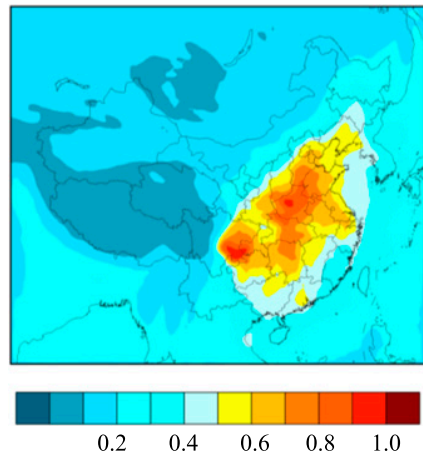

(b)

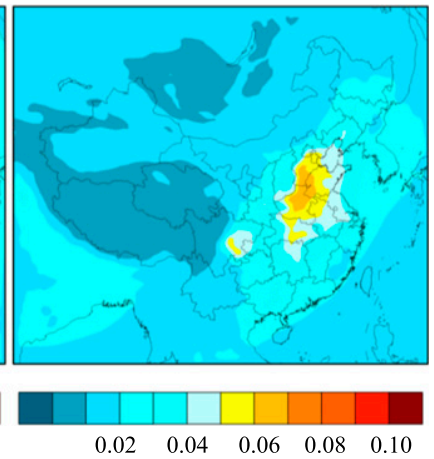

(c)

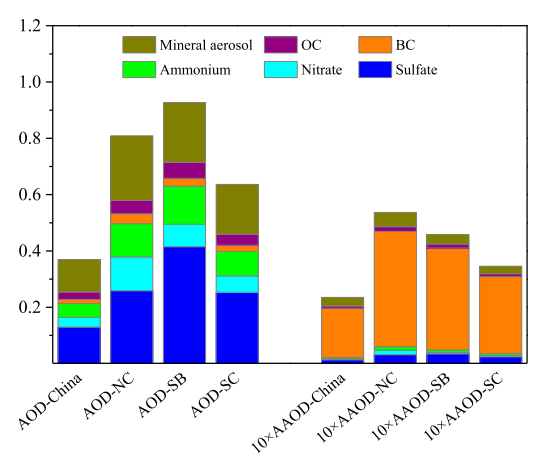

FIG. 9. Spatial distributions of seasonal-mean (a) 600-nm AOD and (b) AAOD from the WRF-Chem simulations; (c) contributions of different species to total aerosol optical depth. 
burden. Figure $9 \mathrm{c}$ presents the simulated annual-mean AOD and AAOD over the whole country and the three typical regions marked in Fig. 1. Nationwide, the annualmean AOD was 0.37 , with the largest contribution from sulfate (0.13), followed by mineral aerosol, nitrates, and ammonium. Sulfate was the most important extinction component at both national and regional scales. The regional average AOD of $\mathrm{NC}$ was as high as 0.81 , and sulfate contributed about $32 \%$. Mineral aerosol and nitrate were also important contributors, accounting for $23 \%$ and $16 \%$, respectively. In the SB, which had total AOD of 0.93 , sulfate AOD even exceeded 0.4, accounting for $45 \%$ of total AOD. As a less-polluted region, SC had a regional mean AOD of 0.64 , of which $40 \%$ resulted from sulfate, $23 \%$ was from mineral aerosol, and $23 \%$ was contributed by nitrate and ammonium. The AAOD is determined mainly by the distribution of $\mathrm{BC}$ and dust. BC AOD was small, but it introduced the majority of AAOD because of its substantial absorption of solar radiation. The national mean AAOD was $0.023,0.018$ of which was ascribed to BC. Seasonally, BC AAOD peaked in winter because of the increase in $\mathrm{BC}$ emissions and subsequent heavy mass load. The national mean AAOD of $\mathrm{BC}$ varied from 0.016 in spring to 0.02 in winter; $\mathrm{NC}$, the $\mathrm{SB}$, and $\mathrm{SC}$ showed similar AAOD seasonal patterns. In NC and the $\mathrm{SB}$, where the winter residential $\mathrm{BC}$ emissions almost doubled, BC AAOD exceeded 0.045 in winter, much higher than the values of $\sim 0.03$ in the other three seasons. Mineral aerosol was the second AAOD contributor, with a national mean value of 0.002 ; this was attributed to the light-absorbing natural dust. Because of intensive dust emissions, mineral aerosol AAOD rose to 0.003 in spring. This spring increase was most distinct in NC, where the dust AAOD increased from a typical value of 0.003 to 0.006 . It is worth noting that the optical depth of OC may have been underestimated by the model because OC concentration was underestimated, and its absorption was not taken into account (Andreae and Gelencsér 2006).

\section{c. Direct radiative effect}

We estimated the DRE of different aerosol species for both shortwave and longwave radiation, and the shortwave DRE was generally one or two orders of magnitude greater than the longwave DRE. The seasonal-mean DRE of different aerosol species at the top of the atmosphere (TOA), in the atmosphere (ATM), and at the surface (BOT) over China are shown in Fig. 10. At TOA, most species introduced a negative radiative effect, with the largest contribution coming from sulfate $\left(-1.4 \mathrm{~W} \mathrm{~m}^{-2}\right)$; $\mathrm{BC}$ was the exception, yielding a positive effect $\left(+4.5 \mathrm{~W} \mathrm{~m}^{-2}\right)$. It is worth noting

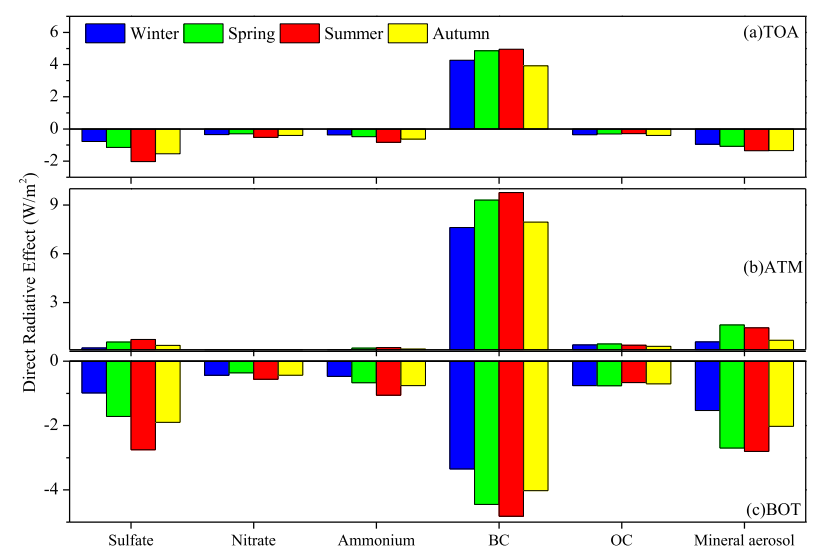

FIG. 10. Seasonal variations in national mean DRE of sulfate, nitrate, ammonium, BC, OC, and mineral aerosol (a) at TOA, (b) in the atmosphere, and (c) at the surface.

that the DRE values of most aerosol species were likely underestimated because of the underpredicted aerosol mass concentrations. Aerosol DRE at the TOA exhibited distinct seasonality, with a summer maximum and a winter minimum. For instance, sulfate DRE at the TOA ranged from $-0.8 \mathrm{Wm}^{-2}$ in winter to $-2.0 \mathrm{~W} \mathrm{~m}^{-2}$ in summer, and BC DRE at TOA varied from $+4.3 \mathrm{~W} \mathrm{~m}^{-2}$ in winter to $+5.0 \mathrm{~W} \mathrm{~m}^{-2}$ in summer. In the atmosphere, aerosols contributed to the total DRE of $+10.8 \mathrm{~W} \mathrm{~m}^{-2}$. $\mathrm{BC}$ was the leading TOA radiative heating aerosol $\left(+8.7 \mathrm{~W} \mathrm{~m}^{-2}\right)$, followed by mineral aerosol $\left(+1.1 \mathrm{~W} \mathrm{~m}^{-2}\right)$. Other nonabsorbing components such as sulfate also displayed a small positive DRE because of their internal mixing with absorbing components and subsequent enhancement of radiation adsorption (Bond et al. 2006). The spatial distribution of atmospheric warming followed the $\mathrm{BC}$ concentration and was consistent with AAOD. BC's atmospheric warming had a distinct seasonality, with a national average summer maximum of $+9.8 \mathrm{~W} \mathrm{~m}^{-2}$ and a winter minimum of $+7.6 \mathrm{~W} \mathrm{~m}^{-2}$, as determined by the seasonality of AAOD and radiation fluxes that peaked in summer and decreased in winter. Atmospheric warming due to mineral aerosol was stronger in spring when the natural dust emission was most intensive. At the surface, all of the aerosol components had negative DRE values because they all either scatter or absorb radiation. BC contributed the majority to the dimming effects, with a seasonal DRE value of -3.3 to $-4.8 \mathrm{~W} \mathrm{~m}^{-2}$. Aerosol reduced the surface radiation over the whole country by up to $10.2 \mathrm{~W} \mathrm{~m}^{-2}$. Nationally, the aerosol surface dimming displayed a summer maximum of $-12.6 \mathrm{~W} \mathrm{~m}^{-2}$ and a winter minimum of $-7.5 \mathrm{~W} \mathrm{~m}^{-2}$.

Generally, the DRE refers to the TOA because it represents the influence a factor has in altering the balance of incoming and outgoing energy in the earth-atmosphere 
(a)

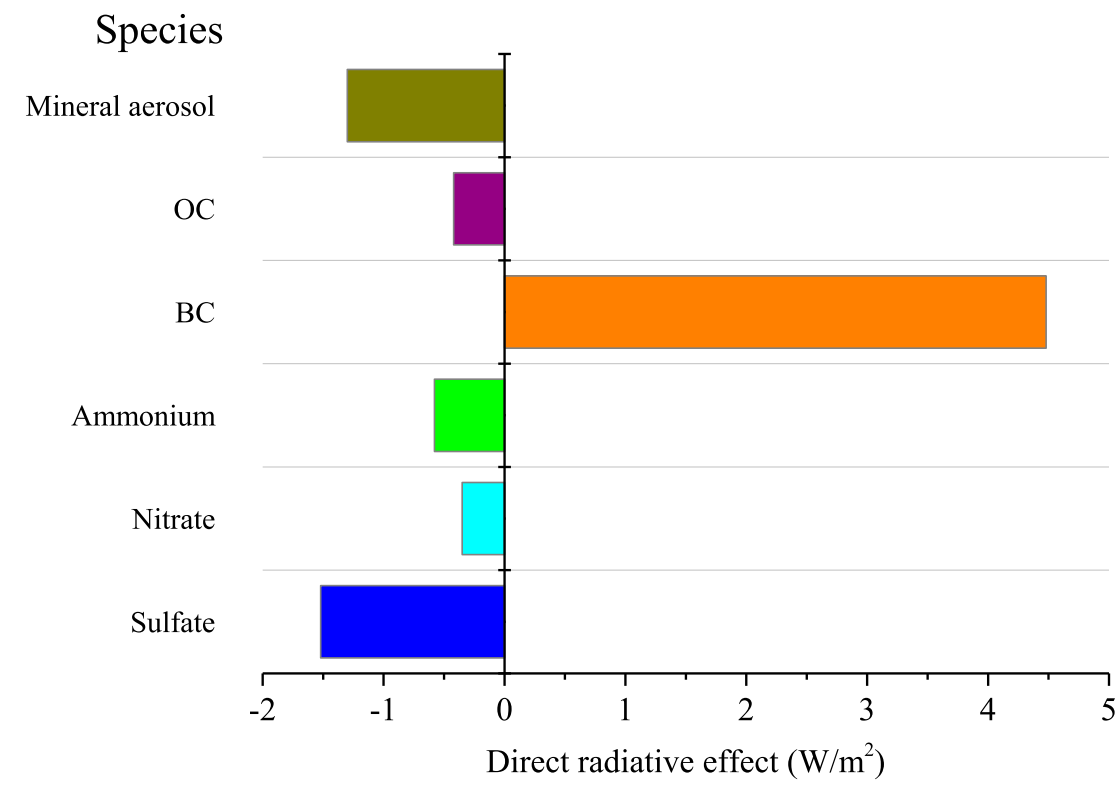

(b)
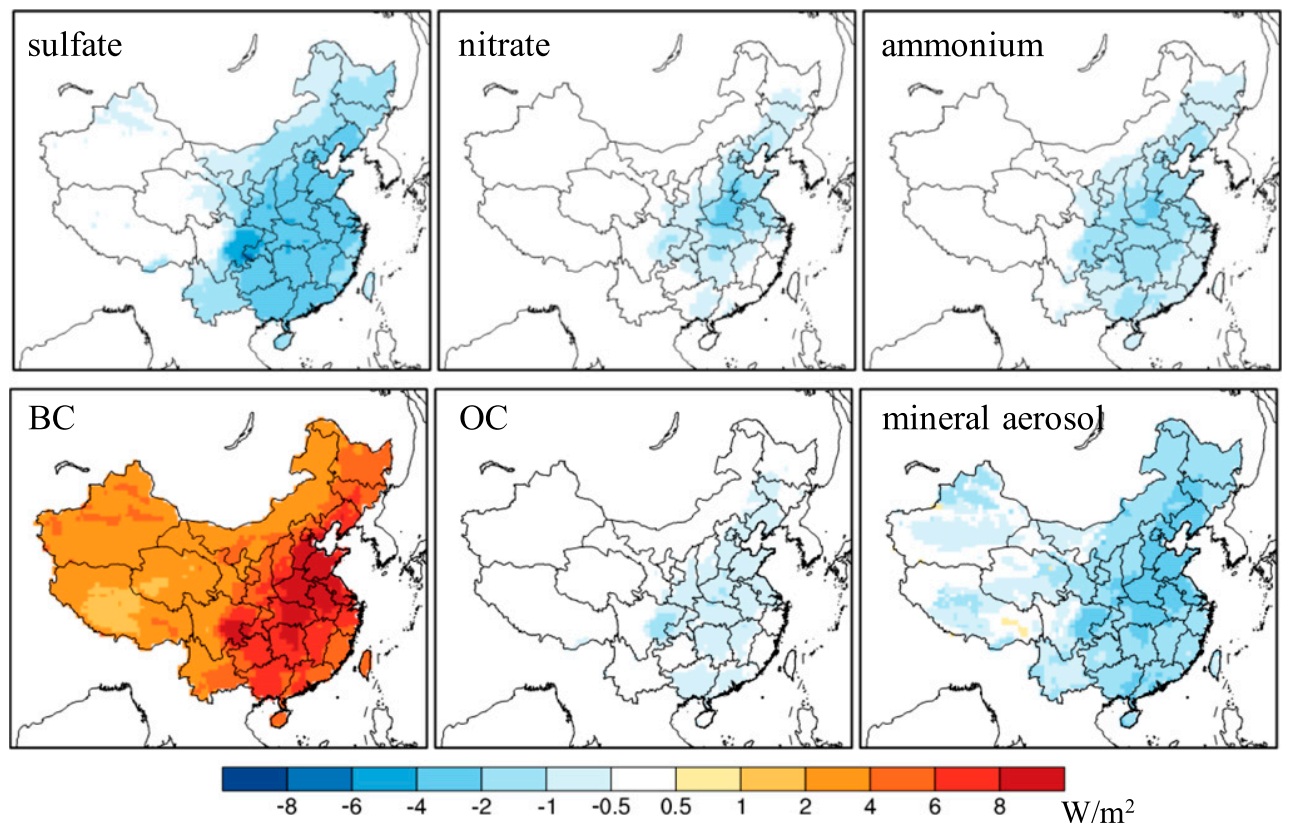

FIG. 11. (a) Annual average aerosol DRE at the TOA and contributions of various aerosol species over China and (b) their spatial distributions.

system (Parry 2007). According to this work, in the year of 2006, aerosols resulted in a small positive DRE at the TOA over China, with an annual average DRE of $+0.6 \mathrm{~W} \mathrm{~m}^{-2}$. It is worth noting that, in this study, OC concentrations were remarkably underpredicted and that the always internally mixed $\mathrm{BC}$ in the model may overamplify absorption (Cappa et al. 2012). Contributions from various aerosol components are shown in Fig. 11a. On average over China the maximum DRE of $+4.5 \mathrm{~W} \mathrm{~m}^{-2}$ was caused by $\mathrm{BC}$; this was followed by sulfate $\left(-1.4 \mathrm{~W} \mathrm{~m}^{-2}\right)$, mineral aerosol $\left(-1.2 \mathrm{~W} \mathrm{~m}^{-2}\right)$, ammonium $\left(-0.6 \mathrm{~W} \mathrm{~m}^{-2}\right)$, nitrate $\left(-0.4 \mathrm{~W} \mathrm{~m}^{-2}\right)$, and OC $\left(-0.3 \mathrm{~W} \mathrm{~m}^{-2}\right)$. Overall, sulfate and $\mathrm{BC}$ were the two most important components in terms of scattering and absorbing radiation. Normalized DRE with respect to the sulfate burden was $-77 \mathrm{~W} \mathrm{~g}^{-1}$, relatively weaker than previous global estimations of -108 to $-354 \mathrm{~W} \mathrm{~g}^{-1}$ for normalized direct radiative forcing (Myhre et al. 2013). Although DRF is calculated as the difference between the reflected solar radiation at the TOA for simulations under present and preindustrial conditions, the DRE of sulfate may be comparable to its DRF over China 
because sulfate aerosol from volcanic origin and other natural sources (e.g., biomass burning) could be negligible compared to that from anthropogenic sources over China. Scattering aerosols are known to efficiently produce radiative perturbation over dark surfaces, so lower normalized DRE of sulfate over China are caused by the high reflectivity of the underlying surface, as oceans are excluded here. Analogously, compared with existing global estimates of the normalized DRE of industrial era $\mathrm{BC}$, which vary from +870 to $+2730 \mathrm{~W} \mathrm{~g}^{-1}$ (Schulz et al. 2006; Bond et al. 2013), an estimate of $+2971 \mathrm{~W} \mathrm{~g}^{-1}$ in this study is pretty high. As mentioned, the land surface albedo over China is greater than the global mean because ocean was not included. BC alters the TOA net radiative balance much more over a bright reflective surface than it does above a dark one. Furthermore, most global models presume an external mixture of BC (Schulz et al. 2006), whereas this study assumed that BC is always internally mixed and therefore amplifies absorption.

Figure $11 \mathrm{~b}$ presents the spatial distributions of annualmean DRE of speciated aerosols at the TOA. BC had a greater DRE in the North China Plain, the middle and lower reaches of the Yangtze River, and the SB, agreeing with mass load distribution. The regional mean BC DRE over $\mathrm{NC}$ and the $\mathrm{SB}$ was +7.9 and $+7.5 \mathrm{Wm}^{-2}$, respectively. The maximum DRE of BC reached approximately $+10.5 \mathrm{~W} \mathrm{~m}^{-2}$ in eastern Henan Province. Because absorbing aerosol is prone to reducing the solar flux reflected from the surface, resulting in a net reduction of radiation to space over high albedo surfaces (Seinfeld and Pandis 2006), the BC DRE at the TOA was higher over the snowy mountains and bright deserts of Tibet and Xinjiang Province. Sulfate DRE levels over $-2.0 \mathrm{~W} \mathrm{~m}^{-2}$ were mostly concentrated in eastern China, particularly in the North China Plain, the middle and lower reaches of the Yangtze River, the Pearl River delta, and the SB. The sulfate radiative cooling effect was most obvious over the $\mathrm{SB}$, with a regional mean DRE of $-4.3 \mathrm{~W} \mathrm{~m}^{-2}$, because of both a high sulfate mass load and significant hygroscopic growth under humid condition. Mainly consisting of quartz, mullite, and calcite dolomite (Gomes and Gillette 1993; Koukouzas et al. 2006; Dai et al. 2010; Y. Zhao et al.2010), mineral aerosol was another important contributor to the interference factor of radiative transfer (Sokolik and Toon 1996; Munoz et al. 2001). It is demonstrated in our simulation that mineral aerosol in China caused DRE of $-1.2 \mathrm{~W} \mathrm{~m}^{-2}$, of which $-0.9 \mathrm{~W} \mathrm{~m}^{-2}$ was ascribed to anthropogenic emissions. OC concentration was underestimated, and absorption by OC (brown carbon) was not treated in this study (Barnard et al. 2010), so the DRE of OC was underestimated. These OC-related biases might lead to an underestimation of aerosolinduced radiative effect.
Aerosol DRE fluctuated seasonally, increasing significantly in summer and decreasing remarkably in winter. The magnitude of aerosol direct radiative effect depended not only on mass burden, physicochemical, and optical properties but also on other conditions such as the incident radiation flux, cloud cover, and the albedo of the underlying Earth surface. Many reasons exist for the summer maximum. First, enhanced atmospheric oxidation capacity in summer accelerated the formation of secondary aerosols. Second, high humidity favored the hygroscopic growth of aerosols in summer, especially sulfate, nitrate, and ammonium. Finally, summer was the season with the highest incoming radiation flux at the TOA, approximately doubling the corresponding flux in winter. By contrast, limited hygroscopic growth and minimum radiation flux reduced the DRE of aerosols in winter. Specifically, sulfate production, hygroscopic growth, and incoming radiation flux were simultaneously highest in summer; thus, sulfate DRE showed an obvious peak in summer $\left(-2.0 \mathrm{~W} \mathrm{~m}^{-2}\right)$, as much as 2.6 times that in winter. In terms of nitrate DRE, the seasonal fluctuation was not as noticeable because low concentrations were accompanied by great hygroscopic growth and enhanced radiation flux in summer, whereas in winter, the reverse was true. Consequently, the nitrate DRE was $-0.5 \mathrm{~W} \mathrm{~m}^{-2}$ in summer, $50 \%$ higher than the corresponding value in winter. Similarly, reverse seasonal variation in $\mathrm{BC}$ concentrations and incident radiation flux led to the fact that the $\mathrm{BC} D \mathrm{DRE}$ in summer was 1.2 times as high as that in winter.

Since the 1990s, aerosol DRE over China has been evaluated by regional models. We compare this estimation with available existing studies. However, it should be noted that most aerosol DRE estimates in those studies refer to the regional mean of the model domain, whereas we calculate the national mean DRE over all land surfaces within the borders of China. As it is, absorption of components like BC have a more distinct warming effect and, simultaneously, the TOA cooling effects of scattering species may be alleviated in this estimation. Wang et al. (2003) and Wu et al. (2004) concluded that sulfate DRE over China was -0.85 and $-0.38 \mathrm{Wm}^{-2}$, respectively, much lower than our estimation. The discrepancy might be ascribed to the following causes: First, the emission inventories in the previous studies were developed for the years 1995 and 2000, when $\mathrm{SO}_{2}$ emissions were much lower than they are in the MEIC inventory for 2008 used in this study. Second, aqueous S(IV) oxidation and heterogeneous reactions are refined in this model, improving the model's performance and also elevating sulfate mass load. Moreover, we note that in those previous studies, the hygroscopicity of sulfate was poorly treated, leading to the underestimation of sulfate DRE. Zhuang et al. (2011) estimated that the BC DRE over China was $+0.75 \mathrm{~W} \mathrm{~m}^{-2}$ 
in 2005. However, $\mathrm{BC}$ emissions from biomass burning were excluded in their work. Additionally, their aerosol schemes only treated BC and did not consider sulfate and nitrate. Consequently, the absence of biomass-burning emissions and mixing with other aerosol species might be responsible for the smaller DRE of BC reported by Zhuang et al. (2011). Gao et al. (2014) indicated that the regional mean DRE of over East Asia $\left(10^{\circ}-50.5^{\circ} \mathrm{N}\right.$, $70^{\circ}-150^{\circ} \mathrm{E}$ ) was $+1.7 \mathrm{~W} \mathrm{~m}^{-2}$. This is comparable to our results excluding DRE over oceans. Their reports of DRE exceeding $+10 \mathrm{~W} \mathrm{~m}^{-2}$ over the SB and the North China Plain in spring and summer are consistent with the present study.

As one of the seriously aerosol-polluted regions, China presents distinct aerosol DRE characteristics compared with other regions. As mentioned, China features high DRE of individual aerosol components because of their high concentrations. In particular, sulfate and BC DRE could reach -1.4 and $+4.5 \mathrm{~W} \mathrm{~m}^{-2}$, respectively, over China. Studies of aerosol DRE in California revealed that the overall DRE was $-1.0 \mathrm{~W} \mathrm{~m}^{-2}$, with sulfate and $\mathrm{BC}$ contributing -0.5 and $+0.4 \mathrm{~W} \mathrm{~m}^{-2}$, respectively (C. Zhao et al. 2013b). The overall TOA cooling effect of aerosol was attributed to the relatively small heating effect of $\mathrm{BC}$ due to extremely low concentrations (less than $1 \mu \mathrm{g} \mathrm{m}^{-3}$ ). In Europe, sulfate DRE were estimated to be $-1.2 \mathrm{~W} \mathrm{~m}^{-2}$ in summer and less than $+0.3 \mathrm{~W} \mathrm{~m}^{-2}$ in winter (Marmer et al. 2007), one-third of the corresponding DRE in China. A lower sulfate concentration, less than $10 \mu \mathrm{g} \mathrm{m}^{-3}$ in Europe, was responsible for the gaps. In India, a developing country like China, BC concentrations are usually as high as $10 \mu \mathrm{g} \mathrm{m}^{-3}$ and even exceed $20 \mu \mathrm{g} \mathrm{m}^{-3}$ in some places, causing TOA heating of about $+6 \mathrm{~W} \mathrm{~m}^{-2}$ (Beegum et al. 2009; Menon et al. 2002). Global-mean DRE due to BC and sulfate was +0.16 to $+0.80 \mathrm{~W} \mathrm{~m}^{-2}$ and $-0.26 \sim-0.82 \mathrm{~W} \mathrm{~m}^{-2}$, respectively (Haywood and Boucher 2000). As discussed, the coexistence of light-absorbing and light-scattering particles in the atmosphere results in weakened and neutralized DRE at the TOA.

\section{d. Uncertainty}

DREs of different aerosol components are roughly corrected based on the normalized DRE as denoted above and the model's biases identified in Fig. 4, assuming that the DRE of one specific aerosol component would change linearly with its mass loading. Nationally, over China the average DRE values due to sulfate, nitrate, ammonium, $\mathrm{BC}, \mathrm{OC}$, and mineral aerosol are $-1.9,-0.7,-0.7,+7.7,-0.7$, and $-1.4 \mathrm{Wm}^{-2}$, respectively, after correction. Note that since internal mixing of $\mathrm{BC}$ is assumed in the model, the correction may not be that accurate. As indicated by Bond et al. (2006), absorption amplification of BC decreases with increasing $\mathrm{BC}$ mass fraction. $\mathrm{BC}$ was underestimated more than sulfate and other scattering components, and thus it is difficult to predict how much the absorption amplification decreases in each size bin.

Simultaneously, uncertainties of simulated aerosol DRE still exist, mostly attributable to the uncertainties in emissions estimation, aerosol optical properties, mixtures, and modeling systems. The contribution of uncertainties in emissions directly translates into uncertainty regarding DRE though the ambient mass load of aerosols. China's emissions are still not well quantified because of the uncertainties of both emission factors and activity levels. In particular, residential combustions were consistently among the dominant sources of BC and OC emissions in China, but with a relatively large uncertainty (Lei et al. 2011). Furthermore, complex refractive indices of various species of aerosol are crucial for optical characteristic simulation. There is a considerable range of values of imaginary part of dust, BC, and OC, which can be because of uncertainties in methods used as well as because of the specific chemical composition from various geographic locations or under different combustion conditions (Sokolik et al. 1993; Andreae and Gelencsér 2006; Moosmuller et al. 2009; Kandler et al. 2007). Besides, radiative absorption is enhanced by the assumption of the internal mixture of atmospheric BC. A recent study concluded that the observed absorption is often less than predicted from observationally constrained theoretical calculations, suggesting that internal mixing may overestimate the TOA warming effect by BC (Cappa et al. 2012). The still incomplete understanding of the radiative effect of $\mathrm{BC}$ with respect to the mixing state is a challenge in aerosol DRE, especially for China, with its dense BC emissions. Furthermore, SOC formation and its coupling with the physical and chemical processes in clouds are poorly recognized. More laboratory and field measurements will benefit better parameterization. Additional challenges include better quantification of the imaginary part of dust, $\mathrm{BC}$, and $\mathrm{OC}$ given the paucity and the incertitude associated with it. Especially, observed lightabsorbing $\mathrm{OC}$ in the atmosphere makes it imperative to reassess and redefine the optical properties of OC and consider it in models (Saleh et al. 2014). To quantify model uncertainties, the SA approach of conducting "one-at-a-time" (OAT) sensitivity tests has been widely used (e.g., Lohmann and Ferrachat 2010). However, OAT tests generally need more than thousands of model runs in order to fully explore the total parameter uncertainty space and are extremely computationally expensive. A more efficient and comprehensive approach 
that populates the statistical distribution of model outputs by sampling hundreds or thousands of possible values for each parameter (e.g., Carslaw et al. 2013; C. Zhao et al. 2013a) could be an effective method to fully quantify the aerosol DRE over China in the future work.

\section{Conclusions}

In this work, the overall direct radiative effect of aerosol and each component's contribution over China were analyzed using a fully coupled meteorologychemistry model for the entire year of 2006. Model simulations were validated with multiple observational datasets, including the measured temperature and relative humidity, concentrations of particulate matters with their chemical components, and ground-based and remotesensing AOD observations. Generally, the modeled results showed the consistency with the observations. The mean biases of simulated daily temperature $2 \mathrm{~m}$ above ground level and relative humidity $2 \mathrm{~m}$ above ground level were less than $\pm 0.7^{\circ} \mathrm{C}$ and $\pm 4 \%$, respectively. The simulations reproduced the observed spatial distributions of aerosol concentrations, showing high mass concentrations in the Beijing-Tianjin-Hebei region, Yangtze River delta, Pearl River delta, and the Sichuan basin. The normalized mean biases of modeled daily $\mathrm{PM}_{10}$ concentrations were within $\pm 30 \%$ at 14 monitoring sites. The model performed well in terms of sulfate, nitrate, ammonium, and mineral aerosol daily concentrations; the normalized mean biases were all within $\pm 40 \%$. However, organic carbon concentrations were substantially underestimated, which is attributed to the deficiency in secondary organic carbon simulation. Black carbon concentration was also underestimated, which was mainly attributed to uncertainties in residential emission estimations. Modeled AOD captured the temporal variations and spatial distributions of ground-based and satellite-derived AOD observations, but with a low bias in magnitude due to underpredicted aerosol mass concentrations.

Aerosols resulted in a small positive DRE at the TOA over China, with the largest contribution coming from $\mathrm{BC}\left(+4.5 \mathrm{~W} \mathrm{~m}^{-2}\right)$, followed by sulfate $\left(-1.4 \mathrm{~W} \mathrm{~m}^{-2}\right)$. The overall DRE of aerosols at the TOA might be relatively small because of the counterbalance between radiative heating $\mathrm{BC}$ and light-scattering constituents such as sulfate, nitrate, and ammonium. In the atmosphere, aerosols led to a total DRE of $+10.8 \mathrm{~W} \mathrm{~m}^{-2}$. BC was the leading radiative heating aerosol $\left(+8.7 \mathrm{~W} \mathrm{~m}^{-2}\right)$, followed by mineral aerosol $\left(+1.1 \mathrm{~W} \mathrm{~m}^{-2}\right)$. At the surface, all of the aerosol components had a radiative cooling effect and jointly resulted in a negative DRE of $-10.2 \mathrm{~W} \mathrm{~m}^{-2}$. Aerosol DRE fluctuated seasonally, increasing significantly in summer and decreasing remarkably in winter. The summer maximum was caused by increased secondary aerosol production, enhanced hygroscopic growth, and elevated incident radiation flux. Considerable uncertainty remains regarding the estimated DRE in this study, which derived from various key components, including residential emission estimation, mixing state, optical properties of aerosol, and extinction vertical distribution. These issues need to be resolved in future work to improve the aerosol simulation and subsequent radiative effect estimation.

Acknowledgments. This work is supported by the National Natural Science Foundation of China under Grants 41275155 and 41121004, the Public Welfare Projects for Environmental Protection (201309009), the National Key Basic Research Program of China (2010CB428501 and 2011CB403401), and the Jiangsu Provincial 2011 Program (Collaborative Innovation Center of Climate Change). Dr. Chun Zhao acknowledges the support by the U.S. DOE as part of the Regional and Global Climate Modeling program. The Pacific Northwest National Laboratory is operated for DOE by Battelle Memorial Institute under Contract DE-AC05-76RL01830. We thank Prof. Xiaoye Zhang for providing CAWNET observational data and the anonymous reviewers for their valuable comments, which greatly improved the quality of the manuscript.

\section{REFERENCES}

Adams, J. W., D. Rodriguez, and R. A. Cox, 2005: The uptake of $\mathrm{SO}_{2}$ on Saharan dust: A flow tube study. Atmos. Chem. Phys., 5, 2679-2689, doi:10.5194/acp-5-2679-2005.

Alexander, B., R. J. Park, D. J. Jacob, and S. L. Gong, 2009: Transition metal-catalyzed oxidation of atmospheric sulfur: Global implications for the sulfur budget. J. Geophys. Res., 114, D02309, doi:10.1029/2008JD010486.

Andreae, M., and A. Gelencsér, 2006: Black carbon or brown carbon? The nature of light-absorbing carbonaceous aerosols. Atmos. Chem. Phys., 6, 3131-3148, doi:10.5194/acp-6-3131-2006.

Ansari, A. S., and S. N. Pandis, 1998: Response of inorganic PM to precursor concentrations. Environ. Sci. Technol., 32, 27062714, doi:10.1021/es971130j.

Barnard, J. C., J. D. Fast, G. Paredes-Miranda, W. Arnott, and A. Laskin, 2010: Technical note: Evaluation of the WRFChem "aerosol chemical to aerosol optical properties" module using data from the MILAGRO campaign. Atmos. Chem. Phys., 10, 7325-7340, doi:10.5194/acp-10-7325-2010.

Barrie, L. A., and Coauthors, 2001: A comparison of large-scale atmospheric sulphate aerosol models (COSAM): Overview and highlights. Tellus, 53B, 615-645, doi:10.1034/ j.1600-0889.2001.530507.x.

Beegum, S. N., and Coauthors, 2009: Spatial distribution of aerosol black carbon over India during pre-monsoon season. Atmos. Environ., 43, 1071-1078, doi:10.1016/j.atmosenv.2008.11.042. 
Bond, T. C., G. Habib, and R. W. Bergstrom, 2006: Limitations in the enhancement of visible light absorption due to mixing state. J. Geophys. Res., 111, D20211, doi:10.1029/ 2006JD007315.

__ , and Coauthors, 2013: Bounding the role of black carbon in the climate system: A scientific assessment. J. Geophys. Res. Atmos., 118, 5380-5552, doi:10.1002/jgrd.50171.

Boucher, O., and M. Pham, 2002: History of sulfate aerosol radiative forcings. Geophys. Res. Lett., 29, 1308, doi:10.1029/ 2001 GL014048.

Buseck, P. R., and M. Pósfai, 1999: Airborne minerals and related aerosol particles: Effects on climate and the environment. Proc. Natl. Acad. Sci. USA, 96, 3372-3379, doi:10.1073/ pnas.96.7.3372

Cao, J., Z. Shen, J. C. Chow, G. Qi, and J. G. Watson, 2009: Seasonal variations and sources of mass and chemical composition for PM10 aerosol in Hangzhou, China. Particuology, 7, 161168, doi:10.1016/j.partic.2009.01.009.

— - X. Tie, W. F. Dabberdt, T. Jie, Z. Zhao, Z. An, Z. Shen, and Y. Feng, 2013: On the potential high acid deposition in northeastern China. J. Geophys. Res. Atmos., 118, 4834-4846, doi:10.1002/jgrd.50381.

Cappa, C. D., and Coauthors, 2012: Radiative absorption enhancements due to the mixing state of atmospheric black carbon. Science, 337, 1078-1081, doi:10.1126/science.1223447.

Carmichael, G., and Coauthors, 2003: Evaluating regional emission estimates using the TRACE-P observations. J. Geophys. Res., 108, 8810, doi:10.1029/2002JD003116.

Carslaw, K. S., and Coauthors, 2013: Large contribution of natural aerosols to uncertainty in indirect forcing. Nature, 503, 67-71, doi:10.1038/nature12674.

Charlson, R. J., J. Langner, H. Rodhe, C. B. Leovy, and S. G. Warren, 1991: Perturbation of the Northern Hemisphere radiative balance by backscattering from anthropogenic sulfate aerosols. Tellus, 43A, 152-163, doi:10.1034/j.1600-0870.1991.00013.x.

Chen, F., and J. Dudhia, 2001: Coupling an advanced land surfacehydrology model with the Penn State-NCAR MM5 modeling system. Part I: Model implementation and sensitivity. Mon. Wea. Rev., 129, 569-585, doi:10.1175/1520-0493(2001)129<0569: CAALSH $>2.0 . \mathrm{CO} ; 2$.

Clarke, A., and Coauthors, 2004: Size distributions and mixtures of dust and black carbon aerosol in Asian outflow: Physiochemistry and optical properties. J. Geophys. Res., 109, D15S09, doi:10.1029/2003JD004378.

Dai, S., L. Zhao, S. Peng, C.-L. Chou, X. Wang, Y. Zhang, D. Li, and Y. Sun, 2010: Abundances and distribution of minerals and elements in high-alumina coal fly ash from the Jungar power plant, Inner Mongolia, China. Int. J. Coal Geol., 81, 320-332, doi:10.1016/j.coal.2009.03.005.

Dentener, F. J., G. R. Carmichael, Y. Zhang, J. Lelieveld, and P. J. Crutzen, 1996: Role of mineral aerosol as a reactive surface in the global troposphere. J. Geophys. Res., 101, 22 869-22 889, doi:10.1029/96JD01818.

Ek, M. B., K. E. Mitchell, Y. Lin, E. Rogers, P. Grunmann, V. Koren, G. Gayno, and J. D. Tarpley, 2003: Implementation of Noah land surface model advances in the National Centers for Environmental Prediction operational mesoscale Eta model. J. Geophys. Res., 108, 8851, doi:10.1029/2002JD003296.

Fairlie, T. D., D. J. Jacob, J. E. Dibb, B. Alexander, M. A. Avery, A. V. Donkelaar, and L. Zhang, 2010: Impact of mineral dust on nitrate, sulfate, and ozone in transpacific Asian pollution plumes. Atmos. Chem. Phys., 10, 3999-4012, doi:10.5194/ acp-10-3999-2010.
Fast, J. D., W. I. Gustafson Jr., R. C. Easter, R. A. Zaveri, J. C. Barnard, E. G. Chapman, G. A. Grell, and S. E. Peckham, 2006: Evolution of ozone, particulates, and aerosol direct radiative forcing in the vicinity of Houston using a fully coupled meteorology-chemistry-aerosol model. J. Geophys. Res., 111, D21305, doi:10.1029/2005JD006721.

Fenter, F. F., F. Caloz, and M. J. Rossi, 1995: Experimental evidence for the efficient "dry deposition" of nitric acid on calcite. Atmos. Environ., 29, 3365-3372, doi:10.1016/1352-2310(95)00183-Y.

Gao, Y., C. Zhao, X. H. Liu, M. G. Zhang, and L. R. Leung, 2014: WRF-Chem simulations of aerosols and anthropogenic aerosol radiative forcing in East Asia. Atmos. Environ., 92, 250266, doi:10.1016/j.atmosenv.2014.04.038.

Gomes, L., and D. A. Gillette, 1993: A comparison of characteristics of aerosol from dust storms in central Asia with soil-derived dust from other regions. Atmos. Environ., 27, 2539-2544, doi:10.1016/0960-1686(93)90027-V.

Goodman, A. L., P. Li, C. R. Usher, and V. H. Grassian, 2001: Heterogeneous uptake of sulfur dioxide on aluminum and magnesium oxide particles. J. Phys. Chem., 105A, 6109-6120, doi:10.1021/jp004423z.

Grell, G. A., S. E. Peckham, R. Schmitz, S. A. McKeen, G. Frost, W. C. Skamarock, and B. Eder, 2005: Fully coupled "online" chemistry within the WRF model. Atmos. Environ., 39, 69576975, doi:10.1016/j.atmosenv.2005.04.027.

Gutman, G., and A. Ignatov, 1998: The derivation of the green vegetation fraction from NOAA/AVHRR data for use in numerical weather prediction models. Int. J. Remote Sens., 19, 1533-1543, doi:10.1080/014311698215333.

Hagler, G., and Coauthors, 2006: Source areas and chemical composition of fine particulate matter in the Pearl River Delta region of China. Atmos. Environ., 40, 3802-3815, doi:10.1016/ j.atmosenv.2006.02.032.

Hanisch, F., and J. N. Crowley, 2001a: The heterogeneous reactivity of gaseous nitric acid on authentic mineral dust samples, and on individual mineral and clay mineral components. Phys. Chem. Chem. Phys., 3, 2474-2482, doi:10.1039/b101700o.

- , and $-2001 \mathrm{~b}$ : Heterogeneous reactivity of gaseous nitric acid on $\mathrm{Al}_{2} \mathrm{O}_{3}, \mathrm{CaCO}_{3}$, and atmospheric dust samples: A Knudsen cell study. J. Phys. Chem., 105A, 3096-3106, doi:10.1021/jp001254+.

Hao, Y., Z. Guo, Z. Yang, M. Fang, and J. Feng, 2007: Seasonal variations and sources of various elements in the atmospheric aerosols in Qingdao, China. Atmos. Res., 85, 27-37, doi:10.1016/j.atmosres.2006.11.001.

Harris, E., and Coauthors, 2013: Enhanced role of transition metal ion catalysis during in-cloud oxidation of $\mathrm{SO}_{2}$. Science, 340, 727-730, doi:10.1126/science.1230911.

Haywood, J., and O. Boucher, 2000: Estimates of the direct and indirect radiative forcing due to tropospheric aerosols: A review. Rev. Geophys., 38, 513-543, doi:10.1029/1999RG000078.

_ L. Donner, A. Jones, and J.-C. Golaz, 2009: Global indirect radiative forcing caused by aerosols: IPCC (2007) and beyond. Clouds in the Perturbed Climate System, J. Heintzenberg and R. J. Charlson, Eds., MIT Press, 451-467.

Hoffmann, M. R., and D. J. Jacob, 1984: Kinetics and mechanisms of the catalytic oxidation of dissolved sulfur dioxide in aqueous solution: An application to nighttime fog water chemistry. SO2, NO, and NO2 Oxidation Mechanisms: Atmospheric Considerations, J. G. Calvert, Ed., Butterworth Publishers, 101-172.

Holben, B., and Coauthors, 2001: An emerging ground-based aerosol climatology: Aerosol optical depth from AERONET. J. Geophys. Res., 106, 12 067-12 097, doi:10.1029/2001JD900014. 
Hsu, N. C., S.-C. Tsay, M. D. King, and J. R. Herman, 2006: Deep blue retrievals of Asian aerosol properties during ACE-Asia. IEEE Trans. Geosci. Remote Sens., 44, 3180-3195, doi:10.1109/ TGRS.2006.879540.

Huang, X., and Coauthors, 2012a: A high-resolution ammonia emission inventory in China. Global Biogeochem. Cycles, 26, GB1030, doi:10.1029/2011GB004161.

— M. Li, J. Li, and Y. Song, 2012b: A high-resolution emission inventory of crop burning in fields in China based on MODIS thermal anomalies/fire products. Atmos. Environ., 50, 9-15, doi:10.1016/j.atmosenv.2012.01.017.

— - Y. Song, M. Li, J. Li, and T. Zhu, 2012c: Harvest season, high polluted season in East China. Environ. Res. Lett., 7, 044033 , doi:10.1088/1748-9326/7/4/044033.

, C. Zhao, M. Li, T. Zhu, Q. Zhang, and X. Zhang, 2014: Pathways of sulfate enhancement by natural and anthropogenic mineral aerosols in China. J. Geophys. Res. Atmos., 119, 14 165-14179, doi:10.1002/2014JD022301.

Huo, Q., X. Cai, L. Kang, H. Zhang, Y. Song, and T. Zhu, 2014: Inference of emission rate using the inverse-dispersion method for the multi-source problem. Agric. For. Meteor., 191, 12-21, doi:10.1016/j.agrformet.2014.02.006.

Jiang, H., H. Liao, H. O. T.Pye, S. Wu, L. J. Mickley, J. H. Seinfeld, and X. Y. Zhang, 2013: Projected effect of 2000-2050 changes in climate and emissions on aerosol levels in China and associated transboundary transport. Atmos. Chem. Phys., 13, 7937-7960, doi:10.5194/acp-13-7937-2013.

Johnson, E. R., J. Sciegienka, S. Carlos-Cuellar, and V. H. Grassian, 2005: Heterogeneous uptake of gaseous nitric acid on dolomite $\left(\mathrm{CaMg}\left(\mathrm{CO}_{3}\right)_{2}\right)$ and calcite $\left(\mathrm{CaCO}_{3}\right)$ particles: A Knudsen cell study using multiple, single, and fractional particle layers. J. Phys. Chem., 109A, 6901-6911, doi:10.1021/ jp0516285.

Justice, C. O., J. R. G. Townshend, E. F. Vermote, E. Masuoka, R. E. Wolfe, N. Saleous, D. P. Roy, and J. T. Morisette, 2002: An overview of MODIS land data processing and product status. Remote Sens. Environ., 83, 3-15, doi:10.1016/ S0034-4257(02)00084-6.

Kanakidou, M., and Coauthors, 2005: Organic aerosol and global climate modelling: A review. Atmos. Chem. Phys., 5, 10531123, doi:10.5194/acp-5-1053-2005.

Kandler, K., and Coauthors, 2007: Chemical composition and complex refractive index of Saharan mineral dust at Izaña, Tenerife (Spain) derived by electron microscopy. Atmos. Environ., 41, 8058-8074, doi:10.1016/j.atmosenv.2007.06.047.

Kasibhatla, P., W. L. Chameides, and J. St. John, 1997: A threedimensional global model investigation of seasonal variations in the atmospheric burden of anthropogenic sulfate aerosols. J. Geophys. Res., 102, 3737-3759, doi:10.1029/96JD03084.

Kiehl, J., and B. Briegleb, 1993: The relative roles of sulfate aerosols and greenhouse gases in climate forcing. Science, $\mathbf{2 6 0}$, 311-314, doi:10.1126/science.260.5106.311.

Kim, D. H., B. J. Sohn, T. Nakajima, T. Takamura, T. Takemura, B. C. Choi, and S. C. Yoon, 2004: Aerosol optical properties over East Asia determined from ground-based sky radiation measurements. J. Geophys. Res., 109, D02209, doi:10.1029/ $2003 J D 003387$.

Kim, J., C. H. Song, Y. Ghim, J. Won, S. Yoon, G. Carmichael, and J.-H. Woo, 2006: An investigation on NH3 emissions and particulate $\mathrm{NH}_{4}^{+}-\mathrm{NO}_{3}^{-}$formation in East Asia. Atmos. Environ., 40, 2139-2150, doi:10.1016/j.atmosenv.2005.11.048.

Knyazikhin, Y., J. V. Martonchik, R. B. Myneni, D. J. Diner, and S. W. Running, 1998: Synergistic algorithm for estimating vegetation canopy leaf area index and fraction of absorbed photosynthetically active radiation from MODIS and MISR data. J. Geophys. Res., 103, 32257-32 275, doi:10.1029/ 98JD02462.

Koukouzas, N. K., R. Zeng, V. Perdikatsis, W. Xu, and E. K. Kakaras, 2006: Mineralogy and geochemistry of Greek and Chinese coal fly ash. Fuel, 85, 2301-2309, doi:10.1016/j.fuel.2006.02.019.

Lei, Y., Q. Zhang, K. He, and D. Streets, 2011: Primary anthropogenic aerosol emission trends for China, 1990-2005. Atmos. Chem. Phys., 11, 931-954, doi:10.5194/acp-11-931-2011.

Levin, Z., E. Ganor, and V. Gladstein, 1996: The effects of desert particles coated with sulfate on rain formation in the eastern Mediterranean. J. Appl. Meteor., 35, 1511-1523, doi:10.1175/ 1520-0450(1996)035<1511:TEODPC $>2.0 . C O ; 2$.

Li, L., Z. Chen, Y. Zhang, T. Zhu, J. Li, and J. Ding, 2006: Kinetics and mechanism of heterogeneous oxidation of sulfur dioxide by ozone on surface of calcium carbonate. Atmos. Chem. Phys., 6, 2453-2464, doi:10.5194/acp-6-2453-2006.

Li, M., X. Huang, J. Li, and Y. Song, 2012: Estimation of biogenic volatile organic compound (BVOC) emissions from the terrestrial ecosystem in China using real-time remote sensing data. Atmos. Chem. Phys. Discuss., 12, 6551-6592, doi:10.5194/ acpd-12-6551-2012.

— , Y. Song, X. Huang, J. Li, Y. Mao, T. Zhu, X. Cai, and B. Liu, 2014: Improving mesoscale modeling using satellite-derived land surface parameters in the Pearl River Delta region, China. J. Geophys. Res. Atmos., 119, 6325-6346, doi:10.1002/ 2014JD021871

Li, S., T. Wang, B. Zhuang, and Y. Han, 2009: Indirect radiative forcing and climatic effect of the anthropogenic nitrate aerosol on regional climate of China. Adv. Atmos. Sci., 26, 543-552, doi:10.1007/s00376-009-0543-9.

Li, W., and L. Shao, 2009: Observation of nitrate coatings on atmospheric mineral dust particles. Atmos. Chem. Phys., 9, 1863-1871, doi:10.5194/acp-9-1863-2009.

Lin, P., and Coauthors, 2009: Seasonal and diurnal variations of organic carbon in $\mathrm{PM}_{2.5}$ in Beijing and the estimation of secondary organic carbon. J. Geophys. Res., 114, D00G11, doi:10.1029/ 2008JD010902.

Liu, C., J. Zhang, and Z. Shen, 2002: Spatial and temporal variability of trace metals in aerosol from the desert region of China and the Yellow Sea. J. Geophys. Res., 107, doi:10.1029/ 2001JD000635.

Liu, J. Y., H. Q. Tian, M. L. Liu, D. F. Zhuang, J. M. Melillo, and Z. X. Zhang, 2005: China's changing landscape during the 1990s: Large-scale land transformations estimated with satellite data. Geophys. Res. Lett., 32, L02405, doi:10.1029/ 2004GL021649.

Lohmann, U., and S. Ferrachat, 2010: Impact of parametric uncertainties on the present-day climate and on the anthropogenic aerosol effect. Atmos. Chem. Phys., 10, 11373-11383, doi:10.5194/acp-10-11373-2010.

— or radiative flux perturbation? Atmos. Chem. Phys., 10, 32353246, doi:10.5194/acp-10-3235-2010.

Loveland, T. R., B. C. Reed, J. F. Brown, D. O. Ohlen, Z. Zhu, L. Yang, and J. W. Merchant, 2000: Development of a global land cover characteristics database and IGBP DISCover from $1 \mathrm{~km}$ AVHRR data. Int. J. Remote Sens., 21, 1303-1330, doi:10.1080/014311600210191.

Lu, Z., and Coauthors, 2010: Sulfur dioxide emissions in China and sulfur trends in East Asia since 2000. Atmos. Chem. Phys., 10, 6311-6331, doi:10.5194/acp-10-6311-2010. 
_ , Q. Zhang, and D. G. Streets, 2011: Sulfur dioxide and primary carbonaceous aerosol emissions in China and India, 19962010. Atmos. Chem. Phys., 11, 9839-9864, doi:10.5194/ acp-11-9839-2011.

Marmer, E., B. Langmann, H. Fagerli, and V. Vestreng, 2007: Direct shortwave radiative forcing of sulfate aerosol over Europe from 1900 to 2000. J. Geophys. Res., 112, D23S17, doi:10.1029/2006JD008037.

Martin, L. R., and T. W. Good, 1991: Catalyzed oxidation of sulfur dioxide in solution: The iron-manganese synergism. Atmos. Environ., 25, 2395-2399, doi:10.1016/0960-1686(91)90113-L.

Mathur, R., and R. L. Dennis, 2003: Seasonal and annual modeling of reduced nitrogen compounds over the eastern United States: Emissions, ambient levels, and deposition amounts. J. Geophys. Res., 108, 4481, doi:10.1029/2002JD002794.

Maxwell-Meier, K., R. Weber, C. Song, D. Orsini, Y. Ma, G. Carmichael, and D. Streets, 2004: Inorganic composition of fine particles in mixed mineral dust-pollution plumes observed from airborne measurements during ACE-Asia. J. Geophys. Res., 109, D19S07, doi:10.1029/2003JD004464.

Menon, S., J. Hansen, L. Nazarenko, and Y. Luo, 2002: Climate effects of black carbon aerosols in China and India. Science, 297, 2250-2253, doi:10.1126/science.1075159.

Mölders, N., 2001: On the uncertainty in mesoscale modeling caused by surface parameters. Meteor. Atmos. Phys., 76, 119141, doi:10.1007/s007030170043.

Moosmuller, H., R. K. Chakrabarty, and W. P. Arnott, 2009: Aerosol light absorption and its measurement: A review. J. Quant. Spectrosc. Radiat. Transfer, 110, 844-878, doi:10.1016/ j.jqsrt.2009.02.035.

Munoz, O., H. Volten, J. D. Haan, W. Vassen, and J. Hovenier, 2001: Experimental determination of scattering matrices of randomly oriented fly ash and clay particles at 442 and $633 \mathrm{~nm}$. J. Geophys. Res., 106, 22 833-22 844, doi:10.1029/2000JD000164.

Myhre, G., F. Stordal, K. Restad, and I. S. Isaksen, 1998: Estimation of the direct radiative forcing due to sulfate and soot aerosols. Tellus, 50B, 463-477, doi:10.1034/j.1600-0889.1998.t01-4-00005.x. , and Coauthors, 2013: Radiative forcing of the direct aerosol effect from AeroCom phase II simulations. Atmos. Chem. Phys., 13, 1853-1877, doi:10.5194/acp-13-1853-2013.

National Bureau of Statistics of China, 2013: China Statistical Yearbook. China Statistics Press, 967 pp.

Nordmann, S., and Coauthors, 2014: Atmospheric black carbon and warming effects influenced by the source and absorption enhancement in central Europe. Atmos. Chem. Phys., 14, 12 683-12 699, doi:10.5194/acp-14-12683-2014.

Pan, L., and Coauthors, 2010: Aerosol optical properties based on ground measurements over the Chinese Yangtze delta region. Atmos. Environ., 44, 2587-2596, doi:10.1016/ j.atmosenv.2010.04.013.

Pandis, S. N., and J. H. Seinfeld, 1989: Sensitivity analysis of a chemical mechanism for aqueous-phase atmospheric chemistry. J. Geophys. Res., 94, 1105-1126, doi:10.1029/JD094iD01p01105.

Park, R. S., C. H. Song, K. M. Han, M. E. Park, S.-S. Lee, S.-B. Kim, and A. Shimizu, 2011: A study on the aerosol optical properties over East Asia using a combination of CMAQ-simulated aerosol optical properties and remote-sensing data via a data assimilation technique. Atmos. Chem. Phys., 11, 12 275-12 296, doi:10.5194/acp-11-12275-2011.

, S. Lee, S.-K. Shin, and C. H. Song, 2014: Contribution of ammonium nitrate to aerosol optical depth and direct radiative forcing by aerosols over East Asia. Atmos. Chem. Phys., 14, 2185-2201, doi:10.5194/acp-14-2185-2014.
Parry, M. L., O. F. Canziani, J. P. Palutikof, P. J. van der Linden, and C. E. Hanson, Eds., 2007: Climate Change 2007: Impacts, Adaptation and Vulnerability. Cambridge University Press, 976 pp.

Paulot, F., D. Jacob, R. Pinder, J. Bash, K. Travis, and D. Henze, 2014: Ammonia emissions in the United States, Europe, and China derived by high-resolution inversion of ammonium wet deposition data: Interpretation with a new agricultural emissions inventory (MASAGE_NH3). J. Geophys. Res. Atmos., 119, 4343-4364, doi:10.1002/2013JD021130.

Pielke, R. A., 2001: Influence of the spatial distribution of vegetation and soils on the prediction of cumulus convective rainfall. Rev. Geophys., 39, 151-177, doi:10.1029/1999RG000072.

Ramanathan, V., and G. Carmichael, 2008: Global and regional climate changes due to black carbon. Nat. Geosci., 1, 221-227, doi:10.1038/ngeo156.

Rosenfeld, D., U. Lohmann, G. B. Raga, C. D. O’Dowd, M. Kulmala, S. Fuzzi, A. Reissell, and M. O. Andreae, 2008: Flood or drought: How do aerosols affect precipitation? Science, 321, 1309-1313, doi:10.1126/science.1160606.

Saleh, R., and Coauthors, 2014: Brownness of organics in aerosols from biomass burning linked to their black carbon content. Nat. Geosci., 7, 647-650, doi:10.1038/ngeo2220.

Samset, B. H., and Coauthors, 2013: Black carbon vertical profiles strongly affect its radiative forcing uncertainty. Atmos. Chem. Phys., 13, 2423-2434, doi:10.5194/acp-13-2423-2013.

Schulz, M., and Coauthors, 2006: Radiative forcing by aerosols as derived from the AeroCom present-day and pre-industrial simulations. Atmos. Chem. Phys., 6, 5225-5246, doi:10.5194/ acp-6-5225-2006.

Seinfeld, J. H., and S. N. Pandis, 2006: Atmospheric Chemistry and Physics: From Air Pollution to Climate Change. Wiley, 1232 pp.

Seisel, S., C. Börensen, R. Vogt, and R. Zellner, 2004: The heterogeneous reaction of $\mathrm{HNO} 3$ on mineral dust and $\gamma$-alumina surfaces: A combined Knudsen cell and DRIFTS study. Phys. Chem. Chem. Phys., 6, 5498-5508, doi:10.1039/b410793d.

Shaw, W. J., K. Jerry Allwine, B. G. Fritz, F. C. Rutz, J. P. Rishel, and E. G. Chapman, 2008: An evaluation of the wind erosion module in DUSTRAN. Atmos. Environ., 42, 1907-1921, doi:10.1016/j.atmosenv.2007.11.022.

Shrivastava, M. K. B., J. D. Fast, R. C. Easter Jr., W. I. Gustafson Jr., R. A. Zaveri, J. L. Jimenez, P. Saide, and A. Hodzic, 2011: Modeling organic aerosols in a megacity: Comparison of simple and complex representations of the volatility basis set approach. Atmos. Chem. Phys., 11, 6639-6662, doi:10.5194/ acp-11-6639-2011.

, A. Zelenyuk, D. Imre, R. C. Easter Jr., J. Beranek, R. A. Zaveri, and J. D. Fast, 2013: Implications of low volatility SOA and gas-phase fragmentation reactions on SOA loadings and their spatial and temporal evolution in the atmosphere. J. Geophys. Res. Atmos., 118, 3328-3342, doi:10.1002/jgrd.50160.

Siefert, R. L., A. M. Johansen, M. R. Hoffmann, and S. O. Pehkonen, 1998: Measurements of trace metal (Fe, $\mathrm{Cu}, \mathrm{Mn}, \mathrm{Cr}$ ) oxidation states in fog and stratus clouds. J. Air Waste Manage. Assoc., 48, 128-143, doi:10.1080/10473289.1998.10463659.

Sokolik, I., and O. B. Toon, 1996: Direct radiative forcing by anthropogenic airborne mineral aerosols. Nature, 381, 681-683, doi:10.1038/381681a0.

—, A. Andronova, and T. C. Johnson, 1993: Complex refractiveindex of atmospheric dust aerosols. Atmos. Environ., 27, 24952502, doi:10.1016/0960-1686(93)90021-P.

Song, Y., D. Chang, B. Liu, W. J. Miao, L. Zhu, and Y. H. Zhang, 2010: A new emission inventory for nonagricultural open fires 
in Asia from 2000 to 2009. Environ. Res. Lett., 5, 014014, doi:10.1088/1748-9326/5/1/014014.

Stelson, A., S. Friedlander, and J. Seinfeld, 1979: A note on the equilibrium relationship between ammonia and nitric acid and particulate ammonium nitrate. Atmos. Environ., 13, 369-371, doi:10.1016/0004-6981(79)90293-2.

Streets, D. G., S. Gupta, S. T. Waldhoff, M. Q. Wang, T. C. Bond, and B. Yiyun, 2001: Black carbon emissions in China. Atmos. Environ., 35, 4281-4296, doi:10.1016/S1352-2310(01)00179-0.

Su, W. Y., N. G. Loeb, G. L. Schuster, M. Chin, and F. G. Rose, 2013: Global all-sky shortwave direct radiative forcing of anthropogenic aerosols from combined satellite observations and GOCART simulations. J. Geophys. Res. Atmos., 118, 655669, doi:10.1029/2012JD018294.

Tang, M., J. Thieser, G. Schuster, and J. Crowley, 2010: Uptake of $\mathrm{NO}_{3}$ and $\mathrm{N}_{2} \mathrm{O}_{5}$ to Saharan dust, ambient urban aerosol and soot: A relative rate study. Atmos. Chem. Phys., 10, 29652974, doi:10.5194/acp-10-2965-2010.

Tao, J., Z. Shen, C. Zhu, J. Yue, J. Cao, S. Liu, L. Zhu, and R. Zhang, 2012: Seasonal variations and chemical characteristics of sub-micrometer particles $\left(\mathrm{PM}_{1}\right)$ in Guangzhou, China. Atmos. Res., 118, 222-231, doi:10.1016/j.atmosres.2012.06.025.

Ullerstam, M., M. S. Johnson, R. Vogt, and E. Ljungstrom, 2003: DRIFTS and Knudsen cell study of the heterogeneous reactivity of $\mathrm{SO}_{2}$ and $\mathrm{NO}_{2}$ on mineral dust. Atmos. Chem. Phys., 3, 2043-2051, doi:10.5194/acp-3-2043-2003.

Underwood, G., C. Song, M. Phadnis, G. Carmichael, and V. Grassian, 2001: Heterogeneous reactions of $\mathrm{NO}_{2}$ and $\mathrm{HNO}_{3}$ on oxides and mineral dust: A combined laboratory and modeling study. J. Geophys. Res., 106, 18 055-18066, doi:10.1029/2000JD900552.

Usher, C. R., H. Al-Hosney, S. Carlos-Cuellar, and V. H. Grassian, 2002: A laboratory study of the heterogeneous uptake and oxidation of sulfur dioxide on mineral dust particles. J. Geophys. Res., 107, 4713, doi:10.1029/2002jd002051.

_ A. E. Michel, and V. H. Grassian, 2003: Reactions on mineral dust. Chem. Rev., 103, 4883-4939, doi:10.1021/cr020657y.

Van Damme, M., and Coauthors, 2014: Global distributions, time series and error characterization of atmospheric ammonia (NH3) from IASI satellite observations. Atmos. Chem. Phys., 14, 2905-2922, doi:10.5194/acp-14-2905-2014.

Wang, T., J. Z. Min, Y. F. Xu, and K. S. Lam, 2003: Seasonal variations of anthropogenic sulfate aerosol and direct radiative forcing over China. Meteor. Atmos. Phys., 84, 185-198, doi:10.1007/s00703-002-0581-7.

— , S. Li, Y. Shen, J. Deng, and M. Xie, 2010: Investigations on direct and indirect effect of nitrate on temperature and precipitation in China using a regional climate chemistry modeling system. J. Geophys. Res., 115, D00K26, doi:10.1029/2009JD013264.

Wang, Y., G. Zhuang, Y. Sun, and Z. An, 2005: Water-soluble part of the aerosol in the dust storm season-Evidence of the mixing between mineral and pollution aerosols. Atmos. Environ., 39, 7020-7029, doi:10.1016/j.atmosenv.2005.08.005.

_ , Q. Zhang, K. He, Q. Zhang, and L. Chai, 2013: Sulfate-nitrateammonium aerosols over China: Response to 2000-2015 emission changes of sulfur dioxide, nitrogen oxides, and ammonia. Atmos. Chem. Phys., 13, 2635-2652, doi:10.5194/acp-13-2635-2013.

Winchester, J. W., L. Weixiu, R. Lixin, W. Mingxing, and W. Maenhaut, 1981: Fine and coarse aerosol composition from a rural area in north China. Atmos. Environ., 15, 933-937, doi:10.1016/0004-6981(81)90093-7.

Wu, J., W. M. Jiang, C. B. Fu, B. K. Su, H. N. Liu, and J. P. Tang, 2004: Simulation of the radiative effect of black carbon aerosols and the regional climate responses over China. $A d v$. Atmos. Sci., 21, 637-649, doi:10.1007/BF02915731.

Xu, J., M. Bergin, R. Greenwald, and P. Russell, 2003: Direct aerosol radiative forcing in the Yangtze delta region of China: Observation and model estimation. J. Geophys. Res., 108, 4060, doi:10.1029/2002JD002550.

Xuan, J., and I. N. Sokolik, 2002: Characterization of sources and emission rates of mineral dust in northern China. Atmos. Environ., 36, 4863-4876, doi:10.1016/S1352-2310(02)00585-X. , G. Liu, and K. Du, 2000: Dust emission inventory in northern China. Atmos. Environ., 34, 4565-4570, doi:10.1016/ S1352-2310(00)00203-X.

Yang, F., and Coauthors, 2011: Characteristics of $\mathrm{PM}_{2.5}$ speciation in representative megacities and across China. Atmos. Chem. Phys., 11, 5207-5219, doi:10.5194/acp-11-5207-2011.

Yang, L., and Coauthors, 2012: Airborne fine particulate pollution in Jinan, China: Concentrations, chemical compositions and influence on visibility impairment. Atmos. Environ., 55, 506514, doi:10.1016/j.atmosenv.2012.02.029.

Ye, B., X. Ji, H. Yang, X. Yao, C. K. Chan, S. H Cadle, T. Chan, and P. A. Mulawa, 2003: Concentration and chemical composition of $\mathrm{PM}_{2.5}$ in Shanghai for a 1-year period. Atmos. Environ., 37, 499-510, doi:10.1016/S1352-2310(02)00918-4.

Zhang, H., Z. Wang, P. Guo, and Z. Wang, 2009: A modeling study of the effects of direct radiative forcing due to carbonaceous aerosol on the climate in East Asia. Adv. Atmos. Sci., 26, 57 66, doi:10.1007/s00376-009-0057-5.

_ Z Z. Shen, X. Wei, M. G. Zhang, and Z. Li, 2012: Comparison of optical properties of nitrate and sulfate aerosol and the direct radiative forcing due to nitrate in China. Atmos. Res., 113, 113-125, doi:10.1016/j.atmosres.2012.04.020.

Zhang, Q., and Coauthors, 2009: Asian emissions in 2006 for the NASA INTEX-B mission. Atmos. Chem. Phys., 9, 5131-5153, doi:10.5194/acp-9-5131-2009.

- K. He, and H. Huo, 2012: Policy: Cleaning China's air. Nature, 484, 161-162, doi:10.1038/484161a.

Zhang, X. Y., R. Arimoto, and Z. S. An, 1997: Dust emission from Chinese desert sources linked to variations in atmospheric circulation. J. Geophys. Res., 102, 28 041-28 047, doi:10.1029/ 97JD02300.

— S. Gong, T. Zhao, R. Arimoto, Y. Wang, and Z. Zhou, 2003: Sources of Asian dust and role of climate change versus desertification in Asian dust emission. Geophys. Res. Lett., 30, 2272, doi:10.1029/2003GL018206.

— , Y. Wang, T. Niu, X. Zhang, S. Gong, Y. Zhang, and J. Sun, 2012: Atmospheric aerosol compositions in China: Spatial/ temporal variability, chemical signature, regional haze distribution and comparisons with global aerosols. Atmos. Chem. Phys., 12, 779-799, doi:10.5194/acp-12-779-2012.

Zhang, Y., 2008: Online-coupled meteorology and chemistry models: History, current status, and outlook. Atmos. Chem. Phys., 8, 2895-2932, doi:10.5194/acp-8-2895-2008.

Zhao, C., and Coauthors, 2013a: Sensitivity of radiative fluxes at top of atmosphere to cloud-microphysics and aerosol parameters in the Community Atmosphere Model (CAM5). Atmos. Chem. Phys., 13, 10 969-10 987, doi:10.5194/acp-13-10969-2013.

_ Characterization of speciated aerosol direct radiative forcing over California. J. Geophys. Res. Atmos., 118, 2372-2388, doi:10.1029/2012JD018364.

Zhao, P., Y. Feng, T. Zhu, and J. Wu, 2006: Characterizations of resuspended dust in six cities of North China. Atmos. Environ., 40, 5807-5814, doi:10.1016/j.atmosenv.2006.05.026. 
-, F. Dong, D. He, X. J. Zhao, X. L. Zhang, W. Z. Zhang, Q. Yao, and H. Y. Liu, 2013: Characteristics of concentrations and chemical compositions for $\mathrm{PM}_{2.5}$ in the region of Beijing, Tianjin, and Hebei, China. Atmos. Chem. Phys., 13, 46314644, doi:10.5194/acp-13-4631-2013.

Zhao, Q., and Coauthors, 2010: Dust storms come to central and southwestern China, too: Implications from a major dust event in Chongqing. Atmos. Chem. Phys., 10, 2615-2630, doi:10.5194/ acp-10-2615-2010.

Zhao, Y., J. Zhang, C. Tian, H. Li, X. Shao, and C. Zheng, 2010: Mineralogy and chemical composition of high-calcium fly ashes and density fractions from a coal-fired power plant in China. Energy Fuels, 24, 834-843, doi:10.1021/ef900947y.

Zheng, J., L. Zhong, T. Wang, P. K. Louie, and Z. Li, 2010: Ground-level ozone in the Pearl River Delta region: Analysis of data from a recently established regional air quality monitoring network. Atmos. Environ., 44, 814-823, doi:10.1016/ j.atmosenv.2009.11.032.

Zhuang, B. L., F. Jiang, T. J. Wang, S. Li, and B. Zhu, 2011: Investigation on the direct radiative effect of fossil fuel blackcarbon aerosol over China. Theor. Appl. Climatol., 104, 301-312, doi:10.1007/s00704-010-0341-4. 